\title{
Long-run Performance of Debt Renegotiations: Large-Sample Evidence
}

\section{By: Tracy Xiang, Wei Wang and Sudipta Basu}

\begin{abstract}
We examine the long-run performance of over 16,000 debt renegotiations. We find that, compared with non-renegotiating firms matched on size, book-to-market, profitability, and investment, renegotiating firms, on average, deliver 10.5 (18.5) percent higher stock returns over the three (five) years following the renegotiation. This renegotiation effect is strongest for waivers and for amendments to loan interest rates and financial covenants. Renegotiations lead to immediate increases in capital expenditures and working capital, but lagged improvements in earnings and cash flow from operations. Renegotiations followed by larger improvements in accounting fundamentals offer better long-run stock performance.
\end{abstract}

Keywords: Debt renegotiations, long-run stock performance, incomplete contracts, financial flexibility, large sample

JEL Codes: G12, G21, G32, M41 


\section{Introduction}

Renegotiation is a key element in contract design. When writing a contract, the parties cannot anticipate and describe all future events, leaving the initial contract incomplete and amenable to future renegotiation. Contract theory suggests that renegotiation leads to mutually beneficial revisions and improves contract ex-post (when new information arrives). ${ }^{1}$ However, renegotiation is not costless, imposing legal and transaction costs and potentially distorting the parties' ex-ante incentives (see, for example, Hart and Tirole 1988). Still, Roberts and Sufi (2009) report that 75 percent of debt contracts are renegotiated before their stated maturity - the vast majority of which occur outside of borrowers' financial distress - suggesting that renegotiation's expected benefits often dominate its expected costs. Given that business debt in the US represents almost 75 percent of gross domestic product (GDP), debt renegotiation, and its consequences, are subjects of economic importance. ${ }^{2}$

In this paper, we provide large-sample evidence on debt renegotiation outcomes. We ask the following questions: (1) What contractual features are amended when the borrower and lender come back to the negotiation table? (2) Does the borrower's long-term performance improve after renegotiation? (3) Does the performance effect vary with the contractual features amended? Much empirical research on debt renegotiation uses relatively small samples (e.g., Roberts 2015) and focuses on specific types of renegotiation, such as covenant modification (e.g., Denis and Wang 2014; Dou 2020). Nikolaev (2018) is the first to examine debt renegotiation in a large-sample setting, but he confines his analysis to the determinants of its frequency. We focus on the outcomes

\footnotetext{
${ }^{1}$ For theoretical papers on contract renegotiation, see, among others, Dye (1985), Hart and Moore (1988, 1998), Bolton (1990), Dewatripont and Maskin (1990), Fudenberg and Tirole (1990), Aghion and Bolton (1992), Aghion, Dewatripont, and Rey (1994), and Demerjian (2017).

${ }^{2}$ See Federal Reserve Bank of St. Louis data on nonfinancial business debt outstanding as a percentage of GDP: https://fred.stlouisfed.org/graph/?g=pD5g.
} 
of debt renegotiation, which encompasses various contractual amendments beyond covenant modifications.

Our sample consists of 16,981 debt renegotiations from 3,453 publicly-listed borrowers over the period 2004 to 2019 . We identify debt renegotiations by parsing Item 1.01 of Form 8 -Ks, which public firms must file with the Securities and Exchange Commission (SEC) upon material corporate events like credit agreement amendments. We build a dictionary of phrases and words (including their variants) that, based on our reading of more than 500 credit amendments, are frequently used to describe contractual changes. We apply this dictionary in our textual analysis program to extract data on amended items in Form 8-K.

We first provide stylized facts about the types of contractual terms amended during renegotiations. Renegotiations on loan amount occur most frequently, representing about one third of the sample renegotiations - the term 'loan amount' is a catchall for modifications to the borrowing capacity, including revisions to the amortized amount of a term loan, the commitment amount of a revolving line of credit, the borrowing base under asset-backed lending, inter alia. About 27 percent of renegotiations modify the maturity (tenor) of the loans, with maturity extensions being far more frequent than maturity curtailment, and 22 percent of renegotiations modify financial covenants. In 13 percent of the renegotiations, lenders grant waiver or consent to borrower actions (like mergers and acquisitions) that would otherwise breach the existing credit agreement. Some renegotiations involve more than one amendment.

Our main analysis examines borrowers' long-run abnormal stock returns after renegotiations. For each renegotiation, we construct a reference portfolio encompassing all CRSP non-renegotiating firms that fall into the same size, book-to-market, profitability, and investment terciles - i.e., risk factors in the Fama and French (2015) five-factor model—of the renegotiating 
firm at the end of the fiscal year before the renegotiation. We follow Lyon, Barber, and Tsai (1999) and compute the passive buy-and-hold returns for the reference portfolios to reduce new listing and rebalancing biases. We examine buy-and-hold abnormal returns, measured as the difference between buy-and-hold monthly returns of renegotiating firm and reference portfolio firms, over horizons of up to five years.

We find that renegotiating firms outperform the reference portfolio firms by 10.5 percent over the three years following the renegotiation. The magnitude of the post-renegotiation abnormal returns becomes even greater over a five-year horizon, averaging 18.4 percent.

We then break up renegotiations into those that elicit positive versus negative short-term market reactions, and examine the long-run stock returns separately for the two groups. The results suggest that firms deliver positive abnormal returns after renegotiations, regardless of whether the market initially viewed them favorably or unfavorably, although the former's long-run performance exceeds the latter's. Our results are robust to alternative specifications including using the leverage ratio and the momentum of stock returns prior to the renegotiation as additional variables to construct the reference portfolio; matching each renegotiating firm with exactly one non-renegotiating firm; and Fama-Macbeth (1973) cross-sectional return regressions.

To understand the driver(s) of the post-renegotiation stock return performance, we inspect borrowers' accounting performance. We find that borrowers' financial flexibility, as reflected by capital expenditures and working capital, increase immediately after renegotiations, whereas cash flow from operations, return on assets, and bankruptcy risk (measured as in Altman (1968) or Ohlson (1980)) exhibit lagged improvements. This lead-lag pattern suggests that renegotiations, on average, enhance borrowers' financial flexibility, allowing them to make long-term capital investments that might not be instantly profitable. We also find that renegotiations generate greater 
abnormal stock returns when they trigger larger improvements in accounting performance. The takeaway is that the stock market does not fully incorporate the long-term implications of the increased financial flexibility and the lagged earnings recovery induced by renegotiations, which is likely because such information is mostly private at the time of the renegotiations.

We next explore heterogeneity in the long-run performance of renegotiations with respect to the amended contractual terms. Renegotiations in which lenders grant waiver or consent to contractual breaches produce the largest returns, averaging 29 (55) percent over a three- (five-) year horizon. These renegotiations reflect lenders' private knowledge about borrowers' future debt service capacity—and the lenders' long-term relationship capital with the borrowersconditioned on the waiver. Amendments to financial covenants and loan interest rates/fees also produce sizeable future abnormal returns, averaging 22.7 (47.2) percent and 13.1 (27.5) percent over the three (five) years after renegotiations.

Several other cross-sectional patterns are noteworthy. First, late-round renegotiations produce larger future returns than do early-round renegotiations. This finding is consistent with the theory in Garleanu and Zwiebel (2009) which posits that, in the presence of information asymmetry about borrowers' future actions, lenders set covenants overly tight to trigger ex-post renegotiations; hence, the initial renegotiations are partly expected and contain less private information compared to the later ones. Second, renegotiations' long-run stock performance is greater among small borrowers and borrowers with low analyst coverage. These firms face greater information frictions, and their stocks are more prone to mispricing. Consistent with renegotiations enhancing financial flexibility for more leveraged borrowers, we find that high-leverage firms deliver larger post-renegotiation stock performance than do low-leverage firms. 
Our paper makes several contributions. First, we contribute to the empirical literature on debt renegotiations (Roberts and Sufi 2009; Denis and Wang 2014; Roberts 2015; Nikolaev 2018) by providing large-sample evidence on the long-run performance of renegotiations and its interplay with amended contract items. Second, we add to the literature examining the long-run performance of significant corporate events like mergers and acquisitions, initial public offerings, and credit rating changes (e.g., Loughran and Ritter 1995; Loughran and Vijh 1997; Spiess and Affleck-Graves 1999; Dichev and Piotroski 2001). Third, we develop a textual-analysis method that allows researchers to analyze renegotiation narratives, especially those regarding the amended contract terms in firms' securities filings.

\section{Theoretical motivation and related literature}

Early theoretical work often assumes away the possibility of renegotiation in deriving the optimal contract or designs "renegotiation-proof" contracts in which renegotiation does not occur in equilibrium (Holmstrom 1979; Bolton and Scharfstein 1990; Dewatripont and Maskin 1990). One argument is that if transacting parties can perfectly specify all possible contingencies-i.e., if information is complete-renegotiations will only hurt the transacting parties. All renegotiated outcomes, if they can be predicted perfectly, can be written costlessly into the original contract. In this framework, a long-term contract incorporating all specified future agreements dominates a sequence of short-term contracts renewed/ revised through renegotiation (Hart and Tirole 1988).

Another rationale for renegotiation-proof contract is the distortions in ex-ante incentives induced by ex-post renegotiation. If the borrower knows in advance that any inefficiencies arising from detrimental actions can be later renegotiated away, it will have no incentive to make efficient investment decisions in the first place - think of a borrower that diverts the cash flows of a debtfinanced construction project while anticipating that its sinister action might be forgiven or only 
weakly penalized by the lender through subsequent renegotiation. ${ }^{3}$ In short, ex-post renegotiation undermines ex-ante efficiency, and therefore in a frictionless world, contracts should not allow for renegotiation.

In practice, however, renegotiations are common and, when they happen, often lead to modifications to various contract terms, contrary to the theoretical arguments above. This observation prompted researchers to explore the role of renegotiations in settings characterized by more realistic constraints. Ball (1989) argues that accounting and auditing are endogenous institutions that arose to make contracts "functionally complete", whereby contracts are written in terms of summary accounting measures of economic states rather than the states themselves. When commenting on the plurality of renegotiations, Bolton (1990) questions whether the phenomenon reflects that "the contracting parties fail to foresee certain contingencies or that they find the contracting costs of writing down renegotiation-proof contracts prohibitive?" Beginning with Aghion and Bolton (1992), the theoretical literature explores renegotiation through the lens of "contractual incompleteness." Aghion and Bolton (1992) study the optimal balance of control between entrepreneur and investor, recognizing that "contracts are inherently incomplete." They find that contingent control allocation (as in debt financing) where the entrepreneur maintains residual control rights in good states of the world and the investor takes over the control rights in bad states of the world. This control allocation contingency dominates either the entrepreneur having full control (as with issuance of nonvoting equity) or the investor having full control (as with issuance of voting equity).

\footnotetext{
${ }^{3}$ Dewatripont and Maskin (1990) provide a classic example. A teacher who wants to make her students study hard, 'contracts' with the students to hold an exam on Tuesday, thus students will study hard on Monday for the exam. But if the teacher gives students the option to 're-contract' and cancel the exam on Tuesday, then the prospect of this recontracting would reduce students' incentives to study hard on Monday.
} 
Under the incomplete contract framework, the transacting parties cannot foresee or describe all future states when drafting the initial contract, thus leaving provisions about the unforeseeable or indescribable future states out of the contract. Such information constraints happen for several reasons. First, there is information asymmetry concerning the borrower's true (unobservable) intent for undertaking the investment project and the level of efforts it commits. Naturally, if the lender does not know the full set of future actions the borrower may or may not take, it cannot possibly know what contingencies to write into a contract governing these actions. Due to the misaligned incentives between the borrower and lender, the incomplete contract problem becomes more acute, and the scope for ex-post renegotiation becomes greater. For example, in Aghion and Bolton (1992), a family business and its lender have conflicting objectives concerning the future developments of the business: whereas the family member may attach nonpecuniary values to the business like family tradition and reputation, the lender only cares about the monetary return, i.e., whether or not it will be repaid on time. These conflicting objectives cannot be perfectly aligned in the initial contract because of contractual incompleteness, creating scope for renegotiation.

Whereas information asymmetry is an important element in contractual incompleteness, it is not a necessary condition. Even in the case where both the lender and borrower are equally informed about the borrower's true intent—i.e., assuming information symmetry—it is possible that neither the borrower nor the lender acting in good faith can perfectly predict future events that are beyond the parties' control but which could alter the ex-post efficiency for both parties (Hart and Moore 1988; Aghion and Bolton 1992; Demerjian 2017). Even in the unlikely case where the transacting parties have a crystal ball and can specify all contingencies, it is prohibitively costly (e.g., countless hours will be spent and large sums of legal fees will be paid) to hammer out detailed 
action plans corresponding to each conceivable future event. Moreover, some information is unverifiable to third parties, such as the court, and therefore is not enforceable and contractible (Hart and Moore 1988). Another source of contractual incompleteness is the transacting parties' bounded rationality. Under bounded rationality, the parties cannot foresee all future events (despite full access to information) and, when they do foresee the future events, they can hardly contract over the anticipated events.

In theory, renegotiation should happen if and only if it produces mutual benefits to the transacting parties, or Pareto improvements, upon the realization of a state of the world (or a signal that is sufficiently highly correlated with that state); otherwise, either or both of the transacting parties can simply refuse to revise the existing loan terms, and the renegotiation breaks down (Christensen et al.2016). The same effect obtains when the borrower commits a technical violation or payment default, which should ordinarily transfer much of the bargaining leverage to the lender. In these cases, renegotiation, if it happens, is more efficient than the alternative solution of asset liquidation. From the borrower's perspective, it can keep at least a portion of the assets by agreeing to the revised terms, even though the borrower must make concessions to compensate the lender for not liquidating assets. From the lender's perspective, it can refuse to renegotiate if it does not believe that revising existing contract terms produce more efficient outcomes than seizing the borrower's assets with low value. Thus, renegotiation mitigates ex-post inefficiencies arising under the prevailing contract terms when new information becomes available. Those efficiency gains form the basis of our paper's inquiry into the long-run performance of debt renegotiations. ${ }^{4}$

\footnotetext{
${ }^{4}$ We focus on the borrower's long-run performance after renegotiations. While it might be interesting to examine the long-run implications of renegotiation from the lender's perspective, it is reasonable to suggest that the borrower's effort and financial condition is much more important to the success of the investment project than the lender's effort and condition. Moreover, in commercial loans, the typical lender extends loans to many different borrowers, making it difficult to map the effects of a particular renegotiation to a lender with multiple debt contracts and possibly multiple renegotiations.
} 


\section{Sample selection and research design}

To systematically identify debt renegotiations and the corresponding contract amendments, we rely on the SEC's requirement that registrants publicly disclose material contracts and amendments thereof. In late 2004, the SEC expanded the scope of corporate events eligible for Form 8-K disclosures under the Securities Exchange Act of 1934, mandating disclosure of any material contractual agreement and any material amendment to the agreement under Item 1.01 (Entry into a Material Definitive Agreement). ${ }^{5}$ If the contract or its amendment is not considered material, the registrant need not issue a Form 8-K. However, in both cases, firms must comply with Item 601 (Exhibits) of Regulation S-K (17 CFR § 229.601) to file the contract as an exhibit in quarterly or annual reports for the fiscal periods in which the contract or the modification becomes effective.

We construct a sample of private debt renegotiations using Item 1.01 of Form 8-Ks. The SEC's disclosure requirements for Form 8-K ensure that our sample contains material contractual amendments, while de minimis changes to debt contracts, such as modifications to boilerplate provisions, are excluded. Several other factors also make Form 8-K desirable. First, firms, by SEC rule, must disclose a brief description of the amended contract terms that are material to the company under Item 1.01 (SEC Release No. 34-49424). This feature lets us identify the revised terms in a renegotiation. Second, because renegotiations occur privately between borrowers and lenders, investors are unlikely to learn about the ongoing renegotiations until firms publicly disclose such events through Form 8-K. Given that the SEC requires a real-time disclosure for Item 1.01 (i.e., within four business days after the amendment), we consider the issuance date of Form 8-K as the time when investors first know about the renegotiation. The market reaction

\footnotetext{
${ }^{5}$ The effective date of the revised filing guidance is August 23, 2004. See the Commission's publication of Release No. 34-49424, Additional Form 8-K Disclosure Requirements and Acceleration of Filing Date.
} 
around this date, therefore, reflects how investors assimilate information contained in the contractual changes to the stock price.

Our sample selection proceeds in the following steps. First, we search for private debt renegotiations disclosed under Item 1.01 of Form 8-K from 2004 to $2019 .{ }^{6}$ The scope of our search is the intersection of Compustat and the SEC filings. We follow Roberts (2015) and Nikolaev (2018) and define renegotiation as an amendment, restatement, modification, or waiver of a credit agreement. A credit agreement is also referred to as "security agreement," "loan agreement," or "financing agreement," and such agreement sometimes includes one or more "facilities" and "revolving lines." To capture all debt renegotiations, we retain Item 1.01s that contain both the words representing credit agreements and those indicating amendments. The typical description for debt renegotiations starts with "XX company entered into the first amendment to the loan agreement..." or "we amended our credit facilities..."

Next, we extend Nikolaev (2018) by identifying the contract terms amended in the renegotiations. One challenge is that Form 8-Ks often depict contractual amendments in highly flexible and non-standardized linguistic formats. To overcome this issue, we carefully read around 500 credit amendments under Item 1.01 and summarize the phrases and words firms use to describe the revised provisions. The most common structure is a combination of words representing changes (e.g., increase, reduce, modify) and words indicating contractual terms (e.g., commitment, maturity, interest rate). The following paragraph is an example from a credit amendment:

The Amendment also modified certain provisions of the Credit Agreement to (among other things): (1) increase the aggregate commitment amount under the Revolving Facility from

\footnotetext{
${ }^{6}$ Strictly speaking, our sample begins from August 24, 2004 since firms start to issue Item 1.01 after the effective date of the revised guidance.
} 
$\$ 750,000,000$ to $\$ 1,000,000,000$; (2) amend the amount by which the aggregate commitment amount under the Revolving Facility may be increased, upon written request by the Company, from $\$ 250,000,000$ to $\$ 500,000,000$; (3) extend the termination date of the Revolving Facility from January 12, 2016, to May 31, 2017; (4) amend the commitment fee rate to a range between $0.100 \%$ and $0.275 \%$ of the unused portion of the Revolving Facility based on a pricing grid tied to the Company's total leverage ratio (as defined in the Credit Agreement).

In this example, the phrases "increase the...commitment," "extend the termination date," and "amend the commitment fee rate" represent a revised commitment, maturity, and pricing terms, respectively. However, some descriptions are not as easy to detect. For example, "Amendment No. 4 allows the Company to sell, transfer, lease or otherwise dispose of its assets to a Subsidiary Guarantor" conveys a modification to negative covenant related to the sale of assets. We use the phrase "allow...to...dispose... assets" to capture such revisions.

We classify nine types of revised terms: (1) new credit issuance, including a new term loan, a new revolving line of credit, etc.; (2) commitment; (3) borrowing base; (4) maturity; (5) pricing terms; (6) financial covenants; (7) consent and waiver; (8) covenants on specific events, like M\&A, debt issuance and redemption, dividends and stock repurchase, capital expenditure and investment, and sale of assets, delayed financial statements, etc.; (9) addition of contractual parties including new borrowers, lenders, and guarantors. ${ }^{7}$ In the empirical analyses, we combine the first three subgroups as "borrowing amount" revisions.

\footnotetext{
${ }^{7}$ For about 20 percent of the credit amendments, we cannot classify the amended contractual terms, either because the firms do not disclose the amended terms, or because they fall outside the scope of the standard amendment types we collect. Appendix A lists the examples of our dictionary. For each type, we randomly select 100 observations and test the accuracy of our classification algorithm and update our dictionary. We repeat the testing step until we could correctly classify over 90 percent of contractual terms in random sample
} 
We further classify the amended terms as favorable or unfavorable depending on whether the revised provisions are less or more restrictive to borrowers. For example, additional (fewer) loan commitments, a maturity extension (curtailment), or a reduction (increase) of interest coverage ratio are favorable (unfavorable) outcomes for the borrower. ${ }^{8}$ We identify twelve times as many favorable amendments as unfavorable amendments. This asymmetry likely arises for two reasons. First, Garleanu and Zwiebel (2009) argue that in the presence of information asymmetry, covenants are set overly tight at the loan inception to facilitate future renegotiations. Thus, when credit agreements are renegotiated ex-post, contractual provisions are more likely to be loosened than tightened. Second, firms are inclined to use neutral words to describe unfavorable amendments. For example, when a firm obtains a lower interest rate, the manager often summarizes the revision as "reduce the interest rate..." However, when the interest rate is increased, the manager likely describes it as "modify the interest rate to..." In those cases, we cannot identify whether the amendments are favorable for the borrower directly from Form 8-Ks.

We collect 16,981 credit amendments from 3,453 firms from Form 8-Ks, which we use to provide descriptive information for contractual amendments. We then merge this sample with CRSP data in two steps. First, to separate renegotiations into those with positive versus negative short-term market reactions, we drop 472 observations with missing values of short-term (3-day) stock returns around announcement dates. This yields a sample of 16,509 renegotiations. Second, when analyzing long-run abnormal stock returns, we require renegotiating firms to have nonmissing values of size, book-to-market, profitability, and investment- - the risk factors we use to form reference portfolios. This step eliminates 660 observations, leaving us with 15,849 renegotiations for the test. In sensitivity tests, the sample size varies depending on the different

\footnotetext{
${ }^{8}$ If we detect contradictory favorableness (e.g., an increase of term loan and a decrease of revolver) within the credit amendment, we do not treat the renegotiation as either favorable or unfavorable.
} 
reference portfolios used. When analyzing changes in firms' accounting performance, we further remove 2,667 observations with missing accounting variables we examine. There are 13,182 credit amendments by 2,804 unique borrowers in that sample.

\section{Research design and empirical results}

\subsection{Summary statistics}

We begin by reporting a few stylized facts about the types and frequency of contract amendments in debt renegotiations, both in the cross-section and over time. As Panel A of Table 1 shows, the most frequently renegotiated item is the borrowing amount, representing around 39 percent of the renegotiations. These renegotiations modify the total loan proceeds a borrower can obtain from the lender, including the lending commitment for a revolving line of credit, the funded and usually amortized amount for a term loan, the borrowing base (maximum amount to be borrowed against collateral) for an asset-based lending transaction, or the accordion provision that allows the borrower to increase its line of credit.

Another frequently renegotiated item is the tenor (maturity) of the loan, which represents 27 percent of the renegotiations. About 20 percent of renegotiations amend interest rates (typically the applicable margin over a benchmark rate like LIBOR or the lender's prime rate) and fees; modifications to the pricing grid, which ties interest rates to borrowers' financial condition like leverage ratio, also belong in this category. Financial covenant modifications account for 22.4 percent of our sample. Given the disciplining effects of financial covenants on borrower actions and their central role in mitigating contractual incompleteness, it is not surprising that banks and borrowers often renegotiate on financial covenants - whether by revising the definition of the accounting metric used in the covenant (for example, by changing how EBITDA is calculated to 
exclude discretionary add-backs) or by adjusting the level of the metric that the borrower must meet to avoid covenant violation.

We also identify renegotiations which amend nonfinancial covenants governing specific corporate events including mergers and acquisitions (M\&As), distribution to equity holders such as dividends and stock repurchases, debt issuances/redemptions, capital investments, asset sales, restricted payments, delivery of financial reporting, and any events related to change of control. The rationale for these covenants - often in the form of negative covenants - is to discourage borrowers from engaging in activities that can significantly alter the borrower's business strategy and capital structure, and from the lender's perspective, adversely change the borrower's debt service capacity. Examination of the data reveals that the majority of amendments of negative covenants permit corporations transactions that are otherwise not allowed under the existing contract. These covenants can be modified concurrently with, or in anticipation of, the underlying corporate events.

Figure 1 presents the detailed breakdown of the underlying transactions: of the 3,737 amendments, 1,367 relate to M\&As, 546 to dividend/stock repurchases, 1,239 to debt issuance/redemption, 770 CAPEX-related to covenants, 219 to asset sales, 220 to restricted payments, 171 to covenants related to the delivery of financial reports. We emphasize that renegotiations often result in amendments to multiple contract terms, so the categories of amended provisions shown in Figure 1 can overlap.

We also identify renegotiations that result in lenders waiving or consenting to borrower actions that are not otherwise allowed under the existing credit agreement. These renegotiations, referred to as "Waiver," "Consent," or "Waiver and Consent," make up around 13 percent of the sample. Waivers and lender consent are responses to borrowers' (expected) violations of any 
affirmative, negative, or financial covenants in place, and are granted when lenders perceive the benefits of allowing the company to carry out its business operations to outweigh the costs of accelerating the loan and prematurely terminating the lending relationship. We exclude from this category contractual amendments made over the normal course of the loan not attributable to the contractual breach. This distinction is important because any material provision amendment, such as interest rate and maturity modifications, normally requires unanimous or super-majority consent among lenders even absent contractual breach. ${ }^{9}$

Renegotiations which add new lenders, borrowers, or guarantors to the existing contracts are infrequent, representing about 2 percent of the sample. In these cases, usually the borrowers or the guarantors added are subsidiaries of the existing borrower,

Although renegotiations could lead to either tightened or loosened loan contract terms, our data suggest that contractual changes are more likely to swing in the borrower's favor. Panel B of Table 1 displays the frequency of favorable and unfavorable renegotiations on borrowing amount, loan maturity, loan pricing, and financial covenants. Favorable (unfavorable) renegotiations are those that render provisions more (less) restrictive for the borrower ${ }^{10}$. Of the 6,594 borrowing amount amendments, more than 74 percent increase the amount. Almost all (96 percent) of loan maturity renegotiations extend the maturity of the loan, which is consistent with contracting parties generally preferring to extend loan facilities through the so-called 'amend and extend' transactions rather than establish a new standalone credit to mitigate refinancing cost (Belluci and McCluskey 2016). Of the 3,352 pricing amendments, 44 percent decrease the interest rates or fees borrowers

\footnotetext{
${ }^{9}$ Interest rate amendments, maturity changes, and covenant changes can happen in conjunction with a waiver/lender consent, in which case we designate the renegotiations a waiver, an interest rate amendment, a maturity amendment, and a covenant amendment.

${ }^{10}$ We cannot specify the direction of some renegotiations for two reasons. First, the firms do not describe the direction of the cases clearly so that we cannot specify its favorableness using textual analysis. Second, we identify both favorable and unfavorable provisions in some cases and cannot conclude the direction of those renegotiations.
} 
pay to the lender, while 23 percent increase interest rates or fees. Among renegotiations for which the direction of the change in the covenant requirements is specified in the 8-Ks, we identify twelve times as many renegotiations that loosen the covenant limits as those which tighten them.

In terms of time-series variation, although the 2008-2010 financial crisis saw a relatively small number of renegotiations, there is a significant dip of favorable amendments during this period, as depicted in Panel A of Figure 2. Panels B to D of Figure 2 display the frequency of favorable and unfavorable debt renegotiations over time for borrowing amount, loan pricing, and financial covenants, respectively. Whereas there are generally more amendments that increase borrowing than those that decrease it during the sample period, the trend reversed in 2009 when renegotiations were more likely to result in loan amount reductions. Similarly, favorable pricing modifications were more common than unfavorable pricing modifications, except between 2008 and 2010. Renegotiations were more likely to loosen covenant restrictions than tighten them throughout the sample period even during the financial crisis, consistent with the model of Garleanu and Zweibel (2009) that lenders purposely set covenants tight at the loan inception, hoping to loosen than over the life of the loan. As Table 2 shows, renegotiations on loan maturity almost always result in loan maturity extension. Waivers and lender consent also peaked in 2009 (see Panel A of Table 1), consistent with many borrowers experiencing financial difficulties and committing payment defaults, technical defaults, or other contract breaches.

We next examine the short-term market reaction around debt renegotiations. Table 2, columns (1) through (3), show the three-day cumulative abnormal returns (CARs) centered around the renegotiation announcement. Consistent with Nikolaev (2018), we find that renegotiations transmit favorable information to the market, generating a 3-day CAR on the magnitude of 37 
basis points (bps). ${ }^{11} \mathrm{We}$ also inspect the market reactions to different types of contractual amendments, extending Nikolaev (2018). Waivers and lender consent produce the largest positive market reaction — hence the greatest amount of private information learned by the market—with a three-day CAR averaging 89 bps. Additions of new contractual parties like borrower subsidiaries and lenders elicit considerable market reaction, with a three-day CAR of $66 \mathrm{bps}$. Amendments to corporate event-specific covenants and loan maturity also produce large three-day CAR of $51 \mathrm{bps}$ and 46 bps, respectively. Market reactions to renegotiations on financial covenants are more muted, averaging 24 bps and statistically indistinguishable from zero $(t$-statistic $=1.58)$. In a later analysis, we use the 3-day CAR surrounding the date of renegotiation announcement as a proxy for the market's initial assessment of the renegotiations' impact on the borrower.

In columns (4) and (5), we examine the cumulative abnormal returns over the [-63, -1$]$ trading day window prior to the renegotiation announcement. This exercise helps us discern the performance record of borrowers leading up to the renegotiation. On average, stocks of renegotiation firms underperform relative to the market leading up to the renegotiation. This finding, together with the positive short-term market reaction to the renegotiation announcement, implies that renegotiations mitigate inefficiencies in the exiting credit agreement as perceived by the market. As before, we separately examine the pre-renegotiation CAR by the types of contractual amendments. We find that loan pricing renegotiations are preceded by reliably negative stock return performance $(\mathrm{CAR}=1.2$ percent; $t$-statistic $=-2.19)$.

\subsection{Computing long-run abnormal stock returns}

To investigate firms' long-run stock performance after renegotiations, we consider the effect of well-known predictors of return, namely firm size, book-to-market ratio, profitability, and

\footnotetext{
${ }^{11}$ Nikolaev (2018) report the 5-day CAR spanning from day -1 to day +3 around the effective date of renegotiation and show that the average 5-day CAR is 29 bps.
} 
investment (Fama and French, 2015). Specifically, our methodology is similar to that in Dichev and Piotroski (2002) and Lyon et al. (1999). We construct the reference portfolios and calculate the buy-and-hold abnormal returns (BHAR) for renegotiating firms as follows:

1. For each calendar month starting from 2004 , we form $81(3 \times 3 \times 3 \times 3)$ portfolios of all CRSP non-renegotiating firms based on their size, book-to-market, profitability, and investment. All the measures are calculated by the data at the end of the previous fiscal year.

2. We assign each renegotiation monthly into one cell of the $3 \times 3 \times 3 \times 3$ matrix of nonrenegotiating benchmark portfolios.

3. To remove the impact of renegotiation on the event month, we calculate the long-run stock performance starting from the second month after the renegotiation. We calculate the three-month, six-month, and the one-, two-, three-, four-, five-year returns for the renegotiating firm and the benchmark portfolio. The BHAR equals the difference between the buy-and-hold return of renegotiating firm and the return of the matched portfolio over a given period. To compute the return of matched portfolio, we assign each firm in the portfolio equal weight or value weight by the firm's size prior to the renegotiations.

We calculate the buy-and-hold returns on a reference portfolio using the following formula:

$$
R_{p s \tau}=\sum_{i=1}^{n_{s}} \frac{\left[\prod_{t=s}^{s+\tau}\left(1+R_{i t}\right)\right]-1}{n_{s}}
$$


where $n_{s}$ is the number of securities traded in month $\mathrm{s}$, the beginning period for the return calculation, and $\tau$ is the horizon to compute the returns. ${ }^{12}$ As a robustness test, we consider the risk factors in the Carhart model as predictors of stock performance by partitioning the nonrenegotiating firms into $125(5 \times 5 \times 5)$ portfolios based on size, book-to-market ratio, and momentum and repeat the above procedure to calculate BHAR.

\subsection{The long-run stock performance of debt renegotiations}

Table 3 presents the long-run abnormal stock returns after debt renegotiations. We report BHARs up to five years after renegotiations. Although somewhat arbitrary, the use of a five-year horizon is customary in the existing literature in long-run event studies (see Loughran and Ritter 1995; Spiess and Affleck-Graves 1995). For completeness, we report annualized returns for 3month, 6-month, and one- to five-year periods, respectively.

Panel A displays the long-run stock performance for the full sample of renegotiations. In row (1), we report the buy-and-hold raw returns of renegotiating firms up to five years after renegotiation. The post-renegotiation returns increase considerably with the length of the buy-andhold period; the average returns equal 41.9 percent over a three-year window, 54.3 percent over a four-year window, and as high as 83.7 percent over a five-year window. Note that these returns are not adjusted for the expected return associated with known risk factors and, therefore, may not necessarily be attributable to the effects of renegotiations per se. Throughout the remainder of the paper, we focus on firms' buy-and-hold abnormal returns after renegotiations.

\footnotetext{
${ }^{12}$ Note that this method represents a passive equally weighted investment in the stocks constituting the matched portfolio - we first compound the returns for each security in the portfolio and then sum across stocks. We do not allow investments in newly listed firms after renegotiating period so that the reference group consists of the same firms throughout the period. Further, the weight of the securities in the reference groups is fixed at the beginning of the calculating period, which prevents rebalancing bias. When a firm in the reference portfolio delists, we assume that the proceeds are reinvested equally among the other firms in the matched group. However, when the renegotiating firm drops out, we assign zero returns for both the focal firm and matched firms for the rest of the period.
} 
We find that renegotiating firms outperform the reference portfolio firms. ${ }^{13}$ In row (2), we report that the BHAR increases monotonically over the holding period. Renegotiating firms experience, on average, 10.5-percent BHAR over a three-year post-renegotiation period, 11.7percent percent BHAR over a four-year period, and 18.4-percent over a five-year period, when benchmarked against the returns of an equally-weighted reference portfolio of non-renegotiating firms. These abnormal returns are statistically significant, with $t$-statistics equal to $4.90,4.71$, and 5.84 for the three-year, four-year, and five-year windows, respectively. Row (3) reports BHARs computed using the returns of a value-weighted reference portfolio firms. Both the economic magnitude and statistical significance of BHARs are almost identical to those in Row (2): for example, the BHAR over a five-year period is 19.2 percent $(t$-statistic $=6.08)$, which is equivalent to an annualized return of 4 percent. ${ }^{14}$ The long-run stock return performance findings suggest that renegotiations create substantial efficiency gains for the borrower, but only a tiny fraction of the benefits are quickly incorporated by the market. A possible reason is that the information contained in the debt amendments as well as the underlying triggering events for the revisions remains largely private despite the public announcement of the renegotiation.

We next partition the renegotiations into two groups based on whether their initial announcements trigger positive or negative short-term market reactions as reflected by the sign of the 3-day CARs. As reported in Panel B, renegotiations' positive future performance is partly driven by those that transmit favorable information to the market initially. For example, the estimates in row (5) indicate that renegotiations with positive 3-day CARs generate, on average, 11.2-percent and 24.6-percent BHARs over a three-year and five-year widow, respectively. This

\footnotetext{
${ }^{13}$ The results are robust if we construct the matching portfolio using Carhart 4-factor model.

${ }^{14}$ To conserve space, we report only the results using equal-weighted reference portfolio going forward, but all our results are robust to using value-weighted reference portfolio.
} 
result is consistent with prior long-run event studies, such as those in the settings of IPO and debt offerings, in which the direction of the short-term market reaction to the event predicts the direction of the long-term abnormal performance after the event, a sign of the market's under-reaction.

Panel $\mathrm{C}$ reports the long-run return performance for renegotiations that trigger a negative short-term market reaction. Surprisingly, even these renegotiations produce long-run abnormal positive returns, outperforming their reference portfolio firms by 9.7 percent over a three-year window. Unlike renegotiations with positive 3-day CARs, the long-run outperformance of renegotiations with negative initial market response does not stretch beyond the third year.

\subsection{Long-run stock performance by amended provisions}

Nearly all contractual provisions are renegotiable, and none of them are exactly the same. Treating renegotiations as a homogenous group masks important variation in the long-run performance attributable to different contractual amendments. In this section, we examine whether the long-run stock performance of renegotiations depends on the contract terms amended in the renegotiations. We focus on renegotiations on loan maturity, loan pricing, financial covenants, covenants governing specific corporate transactions, waivers/lender consent, and additions of new contractual parties.

Table 4 reports the results. All provision amendments are generally associated with longrun positive abnormal returns, but the most significant performance record is observed for renegotiations that amend loan pricing, financial covenants, and corporate event-specific covenants as well as for waivers. Renegotiations on loan pricing terms produce abnormal threeyear-ahead returns of 13.1 percent, and abnormal five-year-ahead returns of 27.5 percent. Renegotiations that modify financial covenants and corporate event-specific covenants generate five-year-ahead returns of 47.2 percent and 69.7 percent, respectively. Borrowers that obtain a 
waiver or lenders' consent through renegotiations outperform the reference portfolio firms by 53.5 percent over five years after the renegotiation.

Loan maturity amendments, in contrast, generate relatively weaker returns, outperforming reference portfolio firms by 6.9 percent (14.0) percent over the three-(five-) year period. Despite the market's strong immediate reaction to additions of new contractual parties, these amendments' future returns are close to zero. Amendments to covenants governing corporate transactions also generate limited long-term returns: the BHAR averages a modest 4.2 percent and 9.3 percent over the three years and five years after renegotiations, respectively. This is likely attributable to offsetting performance records of the underlying transactions. For example, whereas debt and equity issuances have been shown to generate negative long-run abnormal returns (Loughran and Ritter 1995), share repurchases are followed by positive long-run abnormal returns (Ikenberry et al. 1995). To the extent that the various transactions underlying the covenant modifications, if incurred, generate abnormal returns in opposite directions, our signed long-run abnormal returns for the covenant modifications are likely neutralized.

\subsection{Does long-run stock performance vary with the renegotiation round?}

Banks and borrowers often renegotiate many times over the course of the loan. Roberts (2015) reports that the typical loan agreement is renegotiated five times before maturity. The mean (median) loan renegotiation round in our sample is 4.1 (3.5) in the bank-borrower renegotiation sequence. A natural question is whether a renegotiation's long-run performance is related to when the renegotiation happens; for example, do renegotiations that happen in the early phase of the loan tenor generate different long-run performance than renegotiations that take place towards the end of the loan tenor? The renegotiation document (Form 8-K) filed with the SEC, usually in its opening paragraph, states the renegotiation round (i.e., first, second, third, etc.), enabling a 
systematic examination of this question. We extract data on the renegotiation round from Item 1.01 of Form 8-Ks.

Theories provide conflicting predictions on how the timing of the renegotiation (relative to the loan tenor) affects its long-run performance. On the one hand, Garleanu and Zwiebel (2009) show that when there is abundant information asymmetry about borrowers' future opportunistic actions, borrowers and lenders agree to set the initial covenants tight such that a renegotiation will almost certainly occur shortly after the loan is made (when more information becomes available). This pattern is echoed by empirical studies documenting that covenants are usually tight upon loan inception and frequently waived upon renegotiation. Under this line of reasoning, one can argue that early renegotiations (if any) are more of an expected routine event by the transacting parties, conveying information that can be quickly absorbed by the market. Therefore, the long-run outperformance of early-round renegotiations is likely weaker than late-round renegotiations in which triggering events are more unexpected.

On the other hand, it is conceivable that early renegotiations, to the extent they lay the groundwork for future contract term modification, can create the largest contract efficiency gains for the contracting parties and, possibly, the largest information value, for the market; an analogy would be a company with large fixed costs which, while very costly and information intensive in the beginning, can help garner economies of scale in the future. ${ }^{15}$ Under this view, later-round renegotiations provide small incremental contract efficiency gains and, thus, more easily interpreted information. Thus, the long-run outperformance of renegotiations can be more pronounced for early round renegotiations that those that happen later.

\footnotetext{
${ }^{15}$ Or an academic journal peer-review process whereby the initial rounds of revision tends to generate the largest improvements in the paper, whereas the later rounds of revisions make more incremental and smaller changes to the paper.
} 
Table 5 displays long-run performance by renegotiation round. We assign renegotiations into three buckets: early-round renegotiations (round one and two), middle-round renegotiations (round three and four), and late-round renegotiations (round five and beyond). ${ }^{16}$ After removing observations with missing round information, there are 5,481, 3,037, and 2,140 renegotiations in the early, middle, and late round, respectively. The results suggest that later-round renegotiations are associated with larger post-renegotiation stock performance than earlier-round renegotiations. The three-year BHARs average 6.8 percent for first- and second-round renegotiations, 11.7 percent for second- and fourth-round renegotiations, and 29.5 percent for renegotiations in the fifth round and beyond. This trajectory with respect to the timing of loan renegotiation extends to five-year BHARs. Summarizing, consistent with later-round renegotiations providing greater, and harderto-quickly-interpret, private information to the market than earlier-round renegotiation, the longrun post-renegotiation outperformance is more pronounced for later-round renegotiations.

\subsection{Long-run stock performance conditioned on borrower characteristics}

We next explore heterogeneity in renegotiations' long-run performance with respect to borrower characteristics. We first examine the effects of borrower size and analyst coverage. These two characteristics reflect the degree of information asymmetry about the firm and the level of the firm's liquidity in the stock market, which reflects the role of market mispricing in driving the long-run performance of renegotiations. As we hypothesized earlier, the long-run abnormal performance of renegotiations is likely attributable to the market not fully incorporating the informational content of debt renegotiations and corresponding contract revisions. Smaller firms and firms with lower analyst coverage should have opaque information environments, such that

\footnotetext{
${ }^{16}$ In cases where firms renegotiate multiple private debt agreements at different rounds at the same time, we do not assign these cases to any of the buckets if they include early and middle, middle and late, or early and late renegotiations to obtain clear inference of the impact of the renegotiation roud.
} 
the information content of these firms' renegotiations is difficult to decipher quickly. Additionally, the contractual efficiency gains garnered by those firms, precisely because of their large ex-ante information asymmetries, should be large. As such, we predict that the long-run post-renegotiation outperformance is larger for smaller firms and those with less analyst coverage.

Table 6 reports the results. In Panel A, we assign renegotiation into two groups based on the median value of the borrower's total assets, i.e., small vs. large borrowers, in each year. The results indicate that the long-run stock performance of renegotiations is predominantly driven by small borrowers. For small borrowers, renegotiations are followed by positive abnormal returns of 23.2 percent $(t$-statistic $=5.27)$ over a three-year period and 44.1 percent $(t$-statistic $=6.56)$ of a five-year period. In contrast, renegotiations by large borrowers generate negative abnormal buyand-hold returns throughout the five years, though not significant.

In Panel B, we assign renegotiations into two groups based on the median value of the borrower's analyst following in each year. The results echo those in Panel A: the long run performance of renegotiations is greater for firms with below-median analyst following, a setting where the informational content of renegotiations is larger but also harder for the market to decipher quickly. Firms with below-median analyst coverage generate a post-renegotiation abnormal positive return of 21.5 percent $(t$-statistic $=5.42)$ over a three-year period and 37.4 percent $(t$-statistic $=6.44)$ over a five-year period. Firms with above-median analyst coverage, in contrast, generate close-to-zero abnormal returns over the five-year post-renegotiation period. Summarizing, the results are consistent with renegotiations made by smaller borrowers and borrowers with lower analyst coverage containing private information that is hardest for (often small) investors to fully incorporate into stock prices upon renegotiation announcement. 
We next focus on borrowers' leverage ratio. Debt renegotiations should provide greater benefits for more leveraged borrowers through larger effects on the capital structure, debt service capacity, and financial conditions for these borrowers. As such, we expect more leveraged borrowers to provide greater post-renegotiation abnormal stock returns than less leveraged borrowers. To test this prediction, we separate borrowers into two groups based on the median of leverage ratios (total debt scaled by total assets), and report the post-renegotiation abnormal returns separately for the two groups in Panel C. The results support our prediction. Firms with abovemedian leverage ratios generate an average post-renegotiation abnormal stock return of 14.7 percent $(t$-statistic $=3.62)$ over a three-year period, compared to 6.5 -percent $(t$-statistic $=3.86)$ for firms with below-median leverage ratios. Likewise, firms with above-median leverage ratio generate an average post-renegotiation abnormal return of 21.5 percent $(t$-statistic $=4.53)$ over a five-year period, compared to 15.4-percent for firms with below-median leverage ratios ( $t$-statistic $=3.99$ ). These differences are all statically significant according to $t$-tests.

In sum, the cross-sectional heterogeneity in borrower attributes suggests that the long-run stock outperformance of renegotiating firms is greatest for borrowers that are more susceptible to information asymmetry and borrowers that stand to benefit most from renegotiations.

\subsection{The impact of long-run accounting performance of debt renegotiations}

\subsubsection{The behavior of borrowers' accounting performance before and after renegotiations}

To understand the mechanism of the long-run stock performance, we track the behavior of borrowers' accounting performance around renegotiations. We focus on three aspects of accounting performance: (1) financial flexibility, (2) profitability, and (3) bankruptcy risk/ financial distress. We use capital expenditures (scaled by lagged property, plant and equipment) and working capital (scaled by lagged total assets) to capture financial flexibility. More financially 
flexible firms are better positioned to make capital investments and have more working capital for day-to-day operations. To capture profitability, we use both an earnings-based measure (return on assets (ROA)) and a cash-based measure (cash flow from operations divided by assets). Finally, we use two commonly used metrics, Altman's (1968) Z-score and Ohlson's (1980) O-score, to capture borrowers' financial distress or bankruptcy risk.

We estimate the following regression:

$$
\begin{aligned}
&{\text { ACC_PERF }=\beta_{0}}+\beta_{1} \text { Year }_{-2}+\beta_{2} \text { Year }_{-1}+\beta_{3} \text { Year }_{1}+\beta_{4} \text { Year }_{2}+\beta_{5} \text { Year }_{3}+\beta_{6} \text { Year }_{4} \\
&+ \beta_{7} \text { Year }_{5}+\text { Industry FE }+\varepsilon^{-1}
\end{aligned}
$$

Where ACC_PERF represents renegotiating firms' accounting performance, based on the six metrics discussed above, net of reference portfolio firms' accounting performance; the variables of interest are the indicator variables represent years relative to the renegotiation year, with renegotiation year (year 0) being the default case. The coefficients on the year indicator variables reflect the renegotiating firms' performance over and above non-renegotiating firms' performance in a given year, relative to that in the renegotiation year. The event window spans two years before to five years after the renegotiation.

Table 7 reports the regression estimates. We start with the financial flexibility measures.

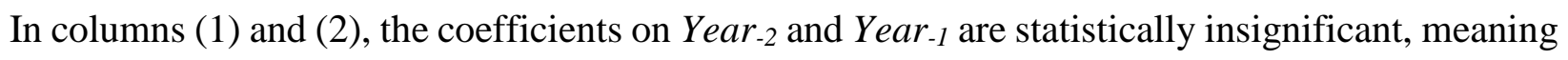
there is no trend in renegotiating firms' capital expenditures relative to non-renegotiating firms' capital expenditures before the renegotiations. Both capital expenditures and working capital increase immediately after renegotiations (the coefficients on year 1 are positive and significant) and stay elevated throughout the remainder of the event window (the coefficients on year 2 through year 5 are positive and significant). Thus, renegotiation has an instant positive impact on borrowers' financial flexibility, which persists in the long term. 
The profitability measures reveal a nuanced pattern. In column (3), borrowers' return on assets drop in the year of the renegotiation compared to their level before the renegotiation, as the coefficient estimates for Year-2 and Year-1 are both positive and statistically significant. The decreased profitability is likely an impetus for the borrowers to renegotiate their debt. The coefficient for Year 1 is close to zero, the coefficient for Year 2 is small and weakly significant, and the coefficients for Year 3 through Year 5 are large, positive, and statistically significant. These findings suggest that firms' earnings do not immediately recover after renegotiations, but increase gradually beginning from year 2. Cash flows from operations display a similar pattern, wherein an initial drop in cash flows surrounding the renegotiation is followed by a gradual recovery over the long term.

We then turn to financial distress measures. Across both Z-score and O-score, renegotiating firms become increasingly distressed leading up to the renegotiation, with distress peaking in the year of renegotiation. Renegotiation immediately reduces firms' financial distress, reflected by the positive (negative) and significant coefficient on $\mathrm{Year}_{1}$ when Z-score (O-score) is the dependent variable. Notably, the coefficients on Year 2 through Year 5 are consistently positive (negative) and significant, indicating renegotiations' long-lasting effect on firms' distress risk.

The findings that improvement in corporate earnings and operating cash flows lag increases in capital expenditures are consistent with the notion that it takes time for companies' capital investments to bear fruit and generate profits. The lead-lag dynamics also point to a plausible driver of the long-run abnormal stock returns: although the market may correctly interpret the drop in short-term profitability and the increase in capital expenditures at the time of the renegotiation, it underestimates the impact of the lagged improvement in earnings and the long-term ramifications of the capital investments. We explore this mechanism further below. 


\subsubsection{The linkage between long-run accounting performance and long-run stock performance}

We link the changes in firms' accounting performance to their stock performance after renegotiations. If the long-run stock performance is driven by renegotiations' effect on accounting fundamentals (and the market's inability to fully incorporate that effect), we expect to observe larger returns for firms with larger improvements in accounting performance. For each renegotiating firm, we compute the change in its accounting performance, using each of the six accounting metrics discussed above, from two years before (the pre-period) to five years after the renegotiation (the post-period), net of the change in reference portfolio firms' accounting performance around the same period. We partition the renegotiation sample based on the median of these changes and report the BHARs for the subgroups. We report the results in Table 8 .

As shown in Panels A and B of Table 8, firms with above-median improvements in capital expenditure and working capital experience 35.6-percent and 40.1-percent BHARs over the fiveyear window compared with reference portfolio firms, respectively. In comparison, firms with below-median changes in these two financial flexibility measures yield meager 4.2-percent and 0.5-percent BHARs over the five year window. Thus, consistent with our prediction, renegotiations that enhance borrowers' financial flexibility produce abnormally higher future stock returns.

In Panels $\mathrm{C}$ and $\mathrm{D}$, we find that firms with above-median change in return on assets and operating cash flow generate five-year-ahead BHARs of 59.7 percent and 52.2 percent. In contrast, firms with below-median changes in these two profitability measures suffer negative five-yearahead BHARs of -21.5 percent and -12.5 percent. This finding suggests that renegotiations' longrun stock return performance is concentrated among firms whose long-term profitability improves after renegotiations. In Panels E and F, we find similarly larger abnormal future returns when firms' 
bankruptcy risk drops by more after renegotiations. Overall, the evidence suggests that renegotiations' long-run stock performance can be at least partly explained by increases in renegotiations' long-run accounting performance which the market does not fully price in at the time of the renegotiation announcement.

\section{Additional analysis}

\subsection{Long-run stock performance of debt renegotiations: one-to-one matching}

Besides using matched reference portfolios, we use one-to-one matching to construct BHAR. Barber and Lyon (1997) document that the "single control firm" approach eliminates skewness bias without introducing a new listing or rebalancing problem. We use two methods to find the matching firm. First, we follow Lyon et al. (1999) and implement the two steps: (1) we identify all firms with similar size of the renegotiating firm (i.e., within 80 percent to 120 percent of the market value of the sample firm); (2) from this set of firms we choose the one with the closest book-to-market equity ratio to the renegotiating firm. The second method we use follows Barber and Lyon (1997) and Teoh et al. (1998). We match each renegotiating firm with one nonrenegotiating firm in the same industry with the closest firm size. For both methods, if the matched firm drops out from the sample before the renegotiating firm, we use the next best match as of the original match date for the remainder of the calculating period.

Table 9 present the results using the two alternative methods to identify control firms. There are 15,738 renegotiations in these tests, a slightly smaller sample than in the main test, because of the different matching criteria. Our results consistently suggest that the renegotiating firms outperform the control firm in the long run. We document a 10.2-percent (15.6-percent) BHAR over three years and a 19.6-percent (27.3-percent) BHAR over five years after the renegotiation when we match by size and book-to-market ratio (by industry and size). This long- 
term positive impact of debt renegotiation is more substantial for a subset of the events with a positive initial market response (see Panel B of Table 9). The abnormal returns become 21.8percent and 32.6-percent over the five-year window, respectively.

Regarding the renegotiations with a negative 3-day CAR around the event, we find a 11.8percent and 15.3 BHAR on average over three years after the event if we identify the matching firm by size and book-to-market ratio and by industry and size, respectively (see Panel C of Table 9). Different from the results using a reference portfolio, the BHAR still increases after three years, but with a lower magnitude than the subset of renegotiating firms with a positive 3 -day CAR. The renegotiating firms outperform their matching firms by 17.4-percent and 22.1 percent over the five-year window by using the two matching methods, respectively.

\subsection{Long-run stock performance of debt renegotiations: Fama-Macbeth approach}

Prior studies argue that simple statistical tests for portfolio means might be misleading due to cross-sectional dependence in returns (e.g., Loughran and Ritter, 1995; Dichev and Piotroski, 2001). This issue may arise in our context because of heterogeneity in the renegotiation intensity (Nikolaev, 2018). Subsequent renegotiations often occur within the specific calculation period, which result in at least some of the overlapping returns. We conduct Fama-Macbeth regressions to address this concern. Using all firms with the risk factors in the Fama-French 5-factor model (i.e., non-missing size, book-to-market equity ratio, profitability, and investment), we regress raw monthly returns on the four factors and an indicator of renegotiation. The renegotiation indicator equals one if the month is within three-months, six-month, one-, two-, three-, four-, and five-years after the firm's credit agreement is amended, and zero otherwise. Note that the regressions are run cross-sectionally for each month during our sample period. The reported coefficient on the 
renegotiation indicator implies the monthly abnormal returns over the specific period; the distribution of the time series of this coefficient is used for statistical testing.

We report the Fama-Macbeth regression results in Table 10. Panel A reports the results for the full sample of renegotiations. The coefficients are significant starting year one after the renegotiation. The monthly abnormal return over the three-year (five-year) window is 22 (24) basis points, which is 2.64 (2.88) percent annualized. We further partition the sample by the initial market response around renegotiations, proxied by the sign of the 3-day CAR. We find that the long-term positive impact pertains to renegotiations which were perceived as positive news by investors in the short term. As documented in Panel B, the annualized abnormal return is 3.6 percent, 2.88 percent, and 3 percent over the one-year, three-year, and five-year window after the renegotiations. In Panel C, we do not observe excess returns for renegotiations with negative initial market reactions.

\section{Conclusion}

Theory suggests that renegotiation allows contracting parties to revise debt in a way that alleviates ex-post inefficiencies and induces mutually beneficial contractual changes. In this paper, we examine the long-run wealth implications of debt renegotiations. Using a sample of more than 16,000 debt renegotiations, we find that borrowers experience significantly positive long-run abnormal stock returns after renegotiations. This renegotiation effect is pervasive, regardless of whether the renegotiation announcements elicit negative or positive market reactions initially. Analyses using accounting performance measures suggest that firms experience immediate increase in capital expenditures and working capital, but more lagged improvements in cash flow from operations, return on assets, and distress risk. Renegotiations followed by larger improvements in accounting performance provide better long-run stock performance. 
We explore heterogeneity in renegotiations' long-run stock performance with respect to the amended item, the renegotiation round, and the borrower's characteristics. The renegotiation effect is largest when the lender grants a waiver or consent to the borrower's actions that would otherwise breach the contract; it is weaker for renegotiations that amend loan maturity and covenants related to specific corporate events like mergers and acquisitions. Later-round renegotiations provide greater long-run abnormal returns than do earlier-round renegotiations. The post-renegotiation outperformance is greater when borrowers are more susceptible to information frictions (i.e., borrowers are smaller and covered by fewer security analysts) and when borrowers can benefit more from the efficiency gains induced by renegotiations (i.e., more leveraged borrowers).

Our evidence suggests that renegotiations produce long-term gains for the borrowers, but these benefits are not fully incorporated by the stock market at the time of the renegotiation announcement. One explanation is that the information (and the triggering events) underlying the renegotiation remains largely private, despite the public announcement of the renegotiation itself, and the future profitability of increased capital investments induced by renegotiations is uncertain ex ante. 


\section{References:}

Aghion, P. and Bolton, P., 1992. An incomplete contracts approach to financial contracting. The Review of Economic Studies 59(3): 473-494.

Aghion, P., Dewatripont, M. and Rey, P., 1994. Renegotiation design with unverifiable information. Econometrica: Journal of the Econometric Society 62(2): 257-282.

Altman, E.I., 1968. Financial ratios, discriminant analysis and the prediction of corporate bankruptcy. The Journal of Finance 23(4): 589-609.

Ball, R., 1989. The firm as a specialist contracting intermediary: Application to accounting and auditing. Working paper, University of Rochester.

Barber, B.M. and Lyon, J.D., 1997. Detecting long-run abnormal stock returns: The empirical power and specification of test statistics. Journal of Financial Economics 43(3): 341-372.

Bellucci, M. and McCluskey, J., 2016. The LSTA's Complete Credit Agreement Guide. McGraw Hill Professional.

Bolton, P., 1990. Renegotiation and the dynamics of contract design. European Economic Review 34(2-3): 303-310.

Carhart, M.M., 1997. On persistence in mutual fund performance. The Journal of Finance 52(1): 57-82.

Christensen, H.B., Nikolaev, V.V. and Wittenberg-Moerman, R., 2016. Accounting information in financial contracting: The incomplete contract theory perspective. Journal of Accounting Research 54(2): 397-435.

Demerjian, P.R., 2017. Uncertainty and debt covenants. Review of Accounting Studies 22(3): 11561197.

Denis, D.J. and Wang, J., 2014. Debt covenant renegotiations and creditor control rights. Journal of Financial Economics 113(3): 348-367.

Dewatripont, M. and Maskin, E., 1990. Contract renegotiation in models of asymmetric information. European Economic Review 34(2-3): 311-321.

Dichev, I.D. and Piotroski, J.D., 2001. The long-run stock returns following bond ratings changes. The Journal of Finance 56(1): 173-203.

Dou, Y., 2020. The debt-contracting value of accounting numbers and financial covenant renegotiation. Management Science 66(3): 1124-1148.

Dye, R.A., 1985. Costly contract contingencies. International Economic Review 26(1): 233-250.

Fama, E.F. and French, K.R., 2015. A five-factor asset pricing model. Journal of Financial Economics 116(1): 1-22.

Fama, E.F. and MacBeth, J.D., 1973. Risk, return, and equilibrium: Empirical tests. Journal of Political Economy 81(3): 607-636.

Fudenberg, D. and Tirole, J., 1990. Moral hazard and renegotiation in agency contracts. Econometrica: Journal of the Econometric Society 58(6): 1279-1319. 
Garleanu, N. and Zwiebel, J., 2009. Design and renegotiation of debt covenants. The Review of Financial Studies 22(2): 749-781.

Hart, O. and Moore, J., 1988. Incomplete contracts and renegotiation. Econometrica: Journal of the Econometric Society 56(4): 755-785.

Hart, O. and Moore, J., 1998. Default and renegotiation: A dynamic model of debt. The Quarterly Journal of Economics 113(1): 1-41.

Hart, O.D. and Tirole, J., 1988. Contract renegotiation and Coasian dynamics. The Review of Economic Studies 55(4): 509-540.

Hölmstrom, B., 1979. Moral hazard and observability. The Bell Journal of Economics 10(1): 7491.

Ikenberry, D., Lakonishok, J. and Vermaelen, T., 1995. Market underreaction to open market share repurchases. Journal of Financial Economics, 39(2-3): 181-208.

Loughran, T. and Ritter, J.R., 1995. The new issues puzzle. The Journal of Finance 50(1): 23-51.

Loughran, T. and Vijh, A.M., 1997. Do long-term shareholders benefit from corporate acquisitions?. The Journal of Finance 52(5): 1765-1790.

Lyon, J.D., Barber, B.M. and Tsai, C.L., 1999. Improved methods for tests of long-run abnormal stock returns. The Journal of Finance 54(1): 165-201.

Nikolaev, V.V., 2018. Scope for renegotiation in private debt contracts. Journal of Accounting and Economics 65(2-3): 270-301.

Ohlson, J.A., 1980. Financial ratios and the probabilistic prediction of bankruptcy. Journal of Accounting Research 18(1): 109-131.

Roberts, M.R., 2015. The role of dynamic renegotiation and asymmetric information in financial contracting. Journal of Financial Economics 116(1): 61-81.

Roberts, M.R. and Sufi, A., 2009. Renegotiation of financial contracts: Evidence from private credit agreements. Journal of Financial Economics 93(2): 159-184.

Spiess, D.K. and Affleck-Graves, J., 1999. The long-run performance of stock returns following debt offerings. Journal of Financial Economics 54(1): 45-73.

Teoh, S.H., Welch, I. and Wong, T.J., 1998. Earnings management and the long-run market performance of initial public offerings. The Journal of finance, 53(6): 1935-1974. 


\section{Appendix A}

\section{Examples of Phrases to Identify Renegotiated Items}

\begin{tabular}{|c|c|}
\hline $\begin{array}{l}\text { Group \#1: } \\
\text { new loans }\end{array}$ & ...new...term loan.../...new...credit facility.../...new...revolver... \\
\hline \multirow{3}{*}{$\begin{array}{l}\text { Group \#2: } \\
\text { commitment }\end{array}$} & $\begin{array}{l}\text { favorable: ...increase...commitment.../ ...provide....incremental...revolving } \\
\text { lines.../ ...committed amount...is raised... }\end{array}$ \\
\hline & $\begin{array}{l}\text { unfavorable: ...lower...amount of credit.../ ...a reduction of...financing } \\
\text { amount.../ ...credit facility...is decreased... }\end{array}$ \\
\hline & $\begin{array}{l}\text { change: ....amend... accordion feature.../ ...the amount...can borrow... is } \\
\text { revised... }\end{array}$ \\
\hline \multirow{3}{*}{$\begin{array}{l}\text { Group \#3: } \\
\text { borrowing } \\
\text { base }\end{array}$} & $\begin{array}{l}\text { favorable: ....add ...to...borrowing base... . ...advance rate...is increased... } \\
\text { / ... an increase of borrowing base... }\end{array}$ \\
\hline & $\begin{array}{l}\text { unfavorable: ....reduce...borrowing capacity.../ ...is removed } \\
\text { from...borrowing base/ .... decrease of...borrowing base... }\end{array}$ \\
\hline & change: ...modifies...borrowing limit.../...borrowing base...redefined... \\
\hline \multirow{3}{*}{$\begin{array}{l}\text { Group \#4: } \\
\text { maturity }\end{array}$} & $\begin{array}{l}\text { favorable: ....renew...term loan...to May } 212015 \ldots / \text {...maturity date....is } \\
\text { increased...by one year.../ ...extension of...expiration date... }\end{array}$ \\
\hline & unfavorable: ....decrease...maturity... \\
\hline & $\begin{array}{l}\text { change: .... a revision of...termination date.../ ... same...except } \\
\text { for...maturity... }\end{array}$ \\
\hline \multirow{3}{*}{$\begin{array}{l}\text { Group \#5: } \\
\text { pricing } \\
\text { terms }\end{array}$} & $\begin{array}{l}\text { favorable: ...lower...interest rate.../ ....spread...is reduced.../ .... a decrease } \\
\text { of....applicable percentages... }\end{array}$ \\
\hline & $\begin{array}{l}\text { unfavorable: ....increase....applicable margin.../ ...commitment fee....is } \\
\text { raised... }\end{array}$ \\
\hline & change: ...update...pricing grid.../ .... modification of...spread... \\
\hline \multirow{3}{*}{$\begin{array}{l}\text { Group \#6: } \\
\text { financial } \\
\text { covenants }\end{array}$} & $\begin{array}{l}\text { favorable: ...increase ...leverage ratio.../ ...fixed charge } \\
\text { ratio...decreased.../ ...financial covenants...to make...less restrictive... }\end{array}$ \\
\hline & $\begin{array}{l}\text { unfavorable: ...increase...interest coverage ratio.../ ....an increase of...ratio of } \\
\text { ebit over assets/ ...eliminates...favorable financial covenants... }\end{array}$ \\
\hline & $\begin{array}{l}\text { change: ...establish...new financial covenants.../ ... revise...net worth } \\
\text { requirement.../ ...quick ratio....is changed... }\end{array}$ \\
\hline
\end{tabular}




\begin{tabular}{|c|c|}
\hline $\begin{array}{c}\text { Group \#7: } \\
\text { waive/consent }\end{array}$ & $\begin{array}{l}\text {...consent and first amendment.../ ... forbearance and } \\
\text { waiver.../ ...waives.../ ...consented to... }\end{array}$ \\
\hline \multirow{8}{*}{$\begin{array}{c}\text { Group \#8: } \\
\text { Corporate event- } \\
\text { specific covenants }\end{array}$} & $\begin{array}{l}\text { M\&A related activities: ...remove...limitations } \\
\text { on....acquisitions.../ ... upon the completion of...merger... }\end{array}$ \\
\hline & $\begin{array}{l}\text { debt issuance/redemption: ....increase...the amount of....senior } \\
\text { notes...issued... }\end{array}$ \\
\hline & $\begin{array}{l}\text { dividends/repurchase: ....allow...to open repurchase.../ ...permitted } \\
\text { dividends...is increased... }\end{array}$ \\
\hline & $\begin{array}{l}\text { CAPX/investments: ...revise...covenants...capital } \\
\text { expenditure.../ ...permit...to make investments... }\end{array}$ \\
\hline & $\begin{array}{l}\text { sale of assets: ....agree to.... sell... business.../ ... allow for... sale } \\
\text { of...properties... }\end{array}$ \\
\hline & $\begin{array}{l}\text { restricted payments: ...increase... restricted payments... } \\
\text { / ...authorize....restricted payments... }\end{array}$ \\
\hline & $\begin{array}{l}\text { delivery of financial statements: ....extension...to deliver...financial } \\
\text { statements/ ... agree on... late delivery of...financial reports... }\end{array}$ \\
\hline & $\begin{array}{l}\text { definition of "change of control": ... relax...the definition of change of } \\
\text { control... . ...modification... change of control definition... }\end{array}$ \\
\hline \multirow{3}{*}{$\begin{array}{c}\text { Group \#9: } \\
\text { Addition of } \\
\text { contractual parties }\end{array}$} & addition of borrowers: ... join... additional borrower... \\
\hline & addition of lenders: ....add...new lender... \\
\hline & addition of guarantors: ... addition of...guarantor... \\
\hline
\end{tabular}


FIGURE 1

Frequency of Corporate-event-specific Covenant Renegotiations by Event

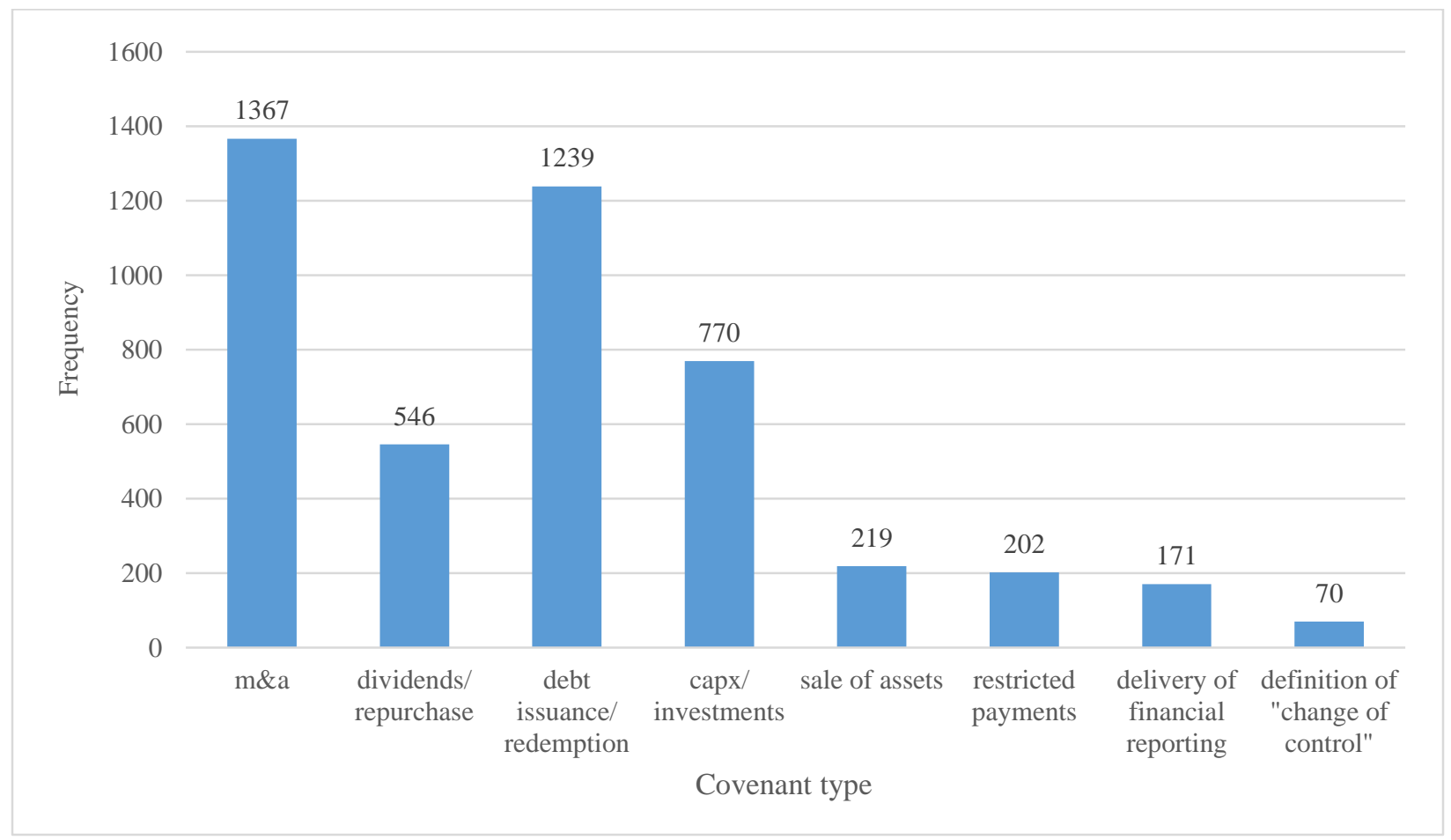

This figure depicts the frequency of renegotiations on different types of corporate-event-specific covenants. We identify six events: mergers and acquisitions, dividends and stock repurchase, debt issuance and debt redemption, capital expenditure and other investments, sale of assets, and late delivery of financial statements. 


\section{FIGURE 2}

Frequency of Favorable and Unfavorable Renegotiations by Year

\section{Panel A: Full sample}

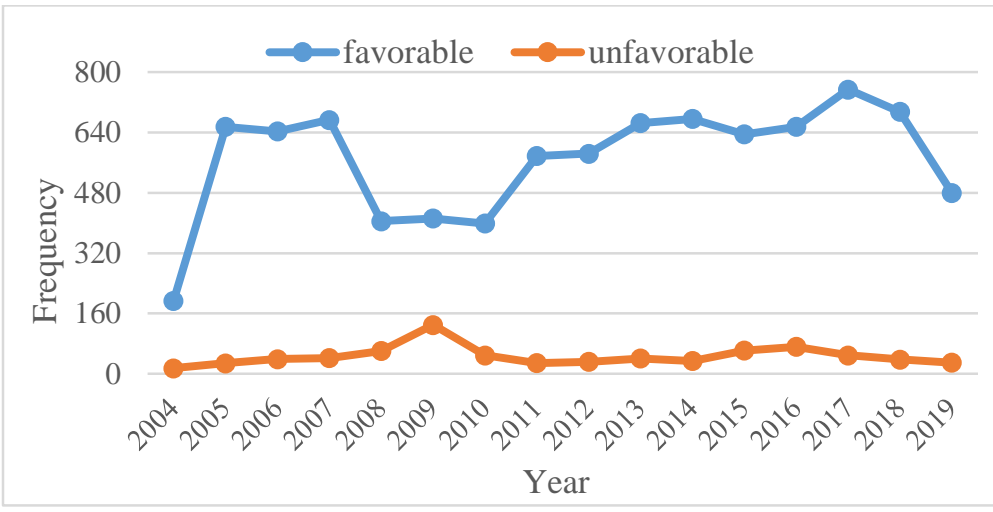

\section{Panel: Pricing terms}

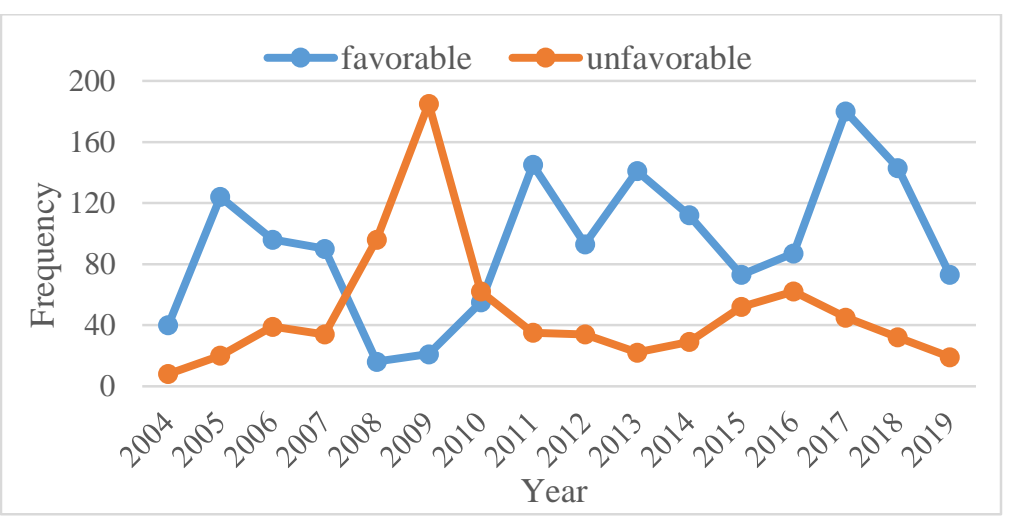

\section{Panel B: Borrowing amount}

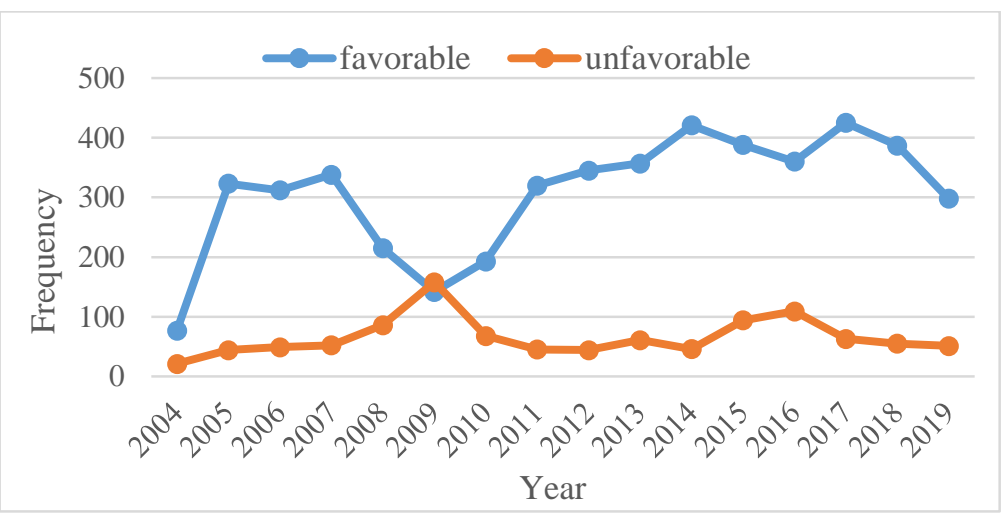

\section{Panel D: Financial covenants}

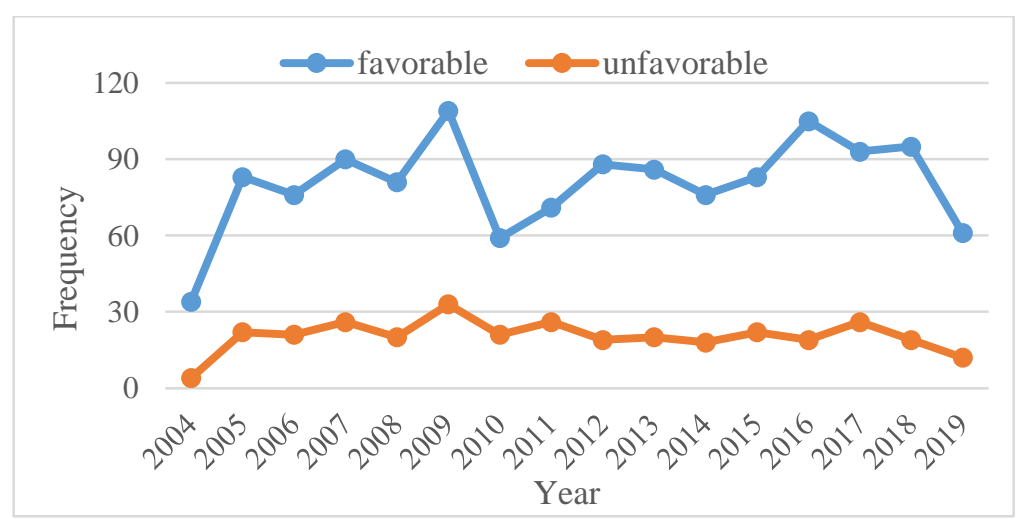

This figure depicts the frequency of favorable and unfavorable renegotiations by year. Favorable renegotiations are those with the revised provisions less restrictive to borrowers (e.g., additional loan commitments, lower interest rate spreads, lower permitted leverage ratio, etc.). Unfavorable renegotiations are those with amended terms more restrictive to borrowers (e.g., reduced commitments, higher interest rate spreads, higher interest coverage ratio required, etc.). Panel A presents the frequency of favorable and unfavorable renegotiations for the full sample. Panels B, C, and D focus on the subsamples of renegotiations on borrowing amount, pricing, and financial covenants, respectively. 
TABLE 1

Summary Statistics of Debt Renegotiations

Panel A: Distribution of debt renegotiations by year and amended item

\begin{tabular}{|c|c|c|c|c|c|c|c|c|}
\hline Year & $\begin{array}{c}\text { All } \\
\text { renegotiations } \\
(1)\end{array}$ & $\begin{array}{c}\text { Borrowing } \\
\text { amount } \\
(2)\end{array}$ & $\begin{array}{c}\text { Maturity } \\
\text { (3) }\end{array}$ & $\begin{array}{c}\text { Pricing } \\
\text { terms } \\
(4)\end{array}$ & $\begin{array}{c}\text { Financial } \\
\text { covenants } \\
(5)\end{array}$ & $\begin{array}{c}\text { Corporate } \\
\text { event-specific } \\
\text { covenants } \\
(6)\end{array}$ & $\begin{array}{c}\text { Waive/ } \\
\text { consent } \\
(7)\end{array}$ & $\begin{array}{l}\text { Addition of } \\
\text { contractual } \\
\text { parties } \\
(8)\end{array}$ \\
\hline 2004 & 370 & 106 & 87 & 61 & 80 & 69 & 49 & 7 \\
\hline 2005 & 1162 & 393 & 300 & 215 & 268 & 276 & 171 & 24 \\
\hline 2006 & 1224 & 402 & 292 & 200 & 242 & 257 & 206 & 23 \\
\hline 2007 & 1188 & 445 & 299 & 205 & 278 & 229 & 191 & 18 \\
\hline 2008 & 936 & 340 & 199 & 194 & 226 & 208 & 153 & 22 \\
\hline 2009 & 1090 & 351 & 264 & 313 & 316 & 216 & 226 & 17 \\
\hline 2010 & 916 & 300 & 240 & 179 & 209 & 223 & 125 & 15 \\
\hline 2011 & 1057 & 409 & 349 & 267 & 218 & 228 & 101 & 21 \\
\hline 2012 & 1093 & 428 & 282 & 188 & 230 & 282 & 97 & 35 \\
\hline 2013 & 1147 & 463 & 347 & 237 & 271 & 230 & 119 & 30 \\
\hline 2014 & 1186 & 513 & 349 & 212 & 244 & 290 & 131 & 29 \\
\hline 2015 & 1249 & 518 & 331 & 199 & 274 & 299 & 129 & 38 \\
\hline 2016 & 1200 & 520 & 310 & 214 & 282 & 271 & 169 & 35 \\
\hline 2017 & 1238 & 542 & 345 & 302 & 268 & 252 & 134 & 27 \\
\hline 2018 & 1153 & 481 & 313 & 232 & 235 & 244 & 127 & 36 \\
\hline 2019 & 772 & 383 & 278 & 134 & 163 & 163 & 57 & 24 \\
\hline Total & 16981 & 6594 & 4585 & 3352 & 3804 & 3737 & 2185 & 401 \\
\hline
\end{tabular}




\section{Panel B: Frequency of favorable and unfavorable renegotiations by amended item}

\begin{tabular}{lccc}
\hline \hline & Favorable & Unfavorable & All \\
& $(1)$ & $(2)$ & $(3)$ \\
\cline { 2 - 4 } Borrowing amount & 4901 & 1046 & 6594 \\
Maturity & 4420 & 3 & 4585 \\
Pricing terms & 1489 & 774 & 3352 \\
Financial covenants & 1290 & 328 & 3804 \\
\hline \hline
\end{tabular}

Panel A reports the distribution of debt renegotiations by year and amended items. Column (1) presents the frequency of debt renegotiations across years. Columns (2) through (7) present the frequency of the renegotiations on borrowing amount, maturity, pricing terms, financial covenants, corporate event-specific covenants, and waivers and consent, respectively. Column (8) presents the frequency of other renegotiations for which we could not identify the amended items. Panel B shows the frequency of favorable and unfavorable renegotiations with amended borrowing amount, maturity, pricing terms, and financial covenants. Favorable renegotiations are those whose revised provisions are less restrictive to borrowers (e.g., additional commitments, lower interest rate, lower permitted leverage ratio, etc.) Unfavorable renegotiations are those with amended terms more restrictive to borrowers (e.g., reduced commitments, higher applicable margin, higher interest coverage ratio required, etc.) Column (1) and (2) do not add up to the number in column (3) for two reasons. In some cases, we cannot identify the direction of amended terms. In other cases, we identify both favorable and unfavorable provisions precludes us from specifying the direction of the renegotiation. 
TABLE 2

Short-term Market Reactions Around Renegotiation Announcement

\begin{tabular}{|c|c|c|c|c|c|}
\hline & & \multicolumn{2}{|c|}{$\operatorname{CAR}(-1,1)$} & \multicolumn{2}{|c|}{ CAR $(-63,-1)$} \\
\hline & $\begin{array}{l}\text { Obs } \\
(1)\end{array}$ & $\begin{array}{c}\text { Mean } \\
(2) \\
\end{array}$ & $\begin{array}{c}t \text {-statistic } \\
(3)\end{array}$ & $\begin{array}{c}\text { Mean } \\
(4) \\
\end{array}$ & $\begin{array}{c}t \text {-statistic } \\
(5)\end{array}$ \\
\hline Full sample & 16,509 & 0.0037 & 4.77 & -0.0044 & -1.79 \\
\hline Borrowing base & 6,427 & 0.0035 & 3.13 & -0.0041 & -1.13 \\
\hline Maturity & 4,464 & 0.0046 & 3.75 & 0.0059 & 1.35 \\
\hline Pricing terms & 3,258 & 0.0028 & 1.81 & -0.0120 & -2.19 \\
\hline Financial covenants & 3,722 & 0.0024 & 1.58 & -0.0049 & -0.89 \\
\hline General covenants & 3,638 & 0.0051 & 2.46 & -0.0041 & -0.83 \\
\hline Waive/consent & 2,097 & 0.0089 & 2.41 & -0.0068 & -0.75 \\
\hline Addition of contractual parties & 391 & 0.0067 & 2.25 & -0.0143 & -1.25 \\
\hline
\end{tabular}

This table presents the short-term market reactions around debt renegotiations. We report the number of observations with non-missing return data in column (1). We report the average market reactions to renegotiations, proxied by the 3 -day CAR centered around the date of 8 -K issuance on credit amendments, and $t$-statistics, in columns (2) and (3), respectively. We report the stock market performance prior to the renegotiation, proxied by the (-63,-1) CAR leading up to the date of 8-K announcements of renegotiations, and $t$-statistics, in columns (4) and (5), respectively. 
TABLE 3

Long-run Abnormal Stock Returns Following Debt Renegotiations

\begin{tabular}{|c|c|c|c|c|c|c|c|c|}
\hline & & 3-month & 6-month & 1-year & 2-year & 3-year & 4-year & 5-year \\
\hline \multicolumn{9}{|c|}{ Panel A: All renegotiations $(15,849$ obs $)$} \\
\hline $\begin{array}{l}\text { BHR } \\
(t \text {-stat })\end{array}$ & $(1)$ & $\begin{array}{l}0.032 \\
(9.59)\end{array}$ & $\begin{array}{c}0.063 \\
(11.73)\end{array}$ & $\begin{array}{c}0.128 \\
(15.44)\end{array}$ & $\begin{array}{c}0.265 \\
(18.23)\end{array}$ & $\begin{array}{c}0.419 \\
(15.77)\end{array}$ & $\begin{array}{c}0.543 \\
(19.82)\end{array}$ & $\begin{array}{c}0.837 \\
(23.58)\end{array}$ \\
\hline $\begin{array}{l}\text { EWBHAR } \\
(t \text {-stat })\end{array}$ & $(2)$ & $\begin{array}{l}0.007 \\
(2.05)\end{array}$ & $\begin{array}{l}0.011 \\
(2.08)\end{array}$ & $\begin{array}{l}0.030 \\
(3.85)\end{array}$ & $\begin{array}{l}0.046 \\
(4.17)\end{array}$ & $\begin{array}{l}0.105 \\
(4.90)\end{array}$ & $\begin{array}{l}0.117 \\
(4.71)\end{array}$ & $\begin{array}{l}0.184 \\
(5.84)\end{array}$ \\
\hline $\begin{array}{l}\text { VWBHAR } \\
(t \text {-stat })\end{array}$ & (3) & $\begin{array}{l}0.008 \\
(2.35)\end{array}$ & $\begin{array}{l}0.013 \\
(2.43)\end{array}$ & $\begin{array}{l}0.033 \\
(4.16)\end{array}$ & $\begin{array}{l}0.050 \\
(4.47)\end{array}$ & $\begin{array}{l}0.108 \\
(5.09)\end{array}$ & $\begin{array}{l}0.123 \\
(4.94)\end{array}$ & $\begin{array}{l}0.192 \\
(6.08)\end{array}$ \\
\hline \multicolumn{9}{|c|}{ Panel B: Renegotiations with positive 3-day announcement CARs (7,888 obs) } \\
\hline $\begin{array}{l}\text { BHR } \\
(t \text {-stat })\end{array}$ & (4) & $\begin{array}{l}0.035 \\
(7.32)\end{array}$ & $\begin{array}{l}0.071 \\
(8.89)\end{array}$ & $\begin{array}{c}0.134 \\
(11.39)\end{array}$ & $\begin{array}{c}0.274 \\
(13.57)\end{array}$ & $\begin{array}{c}0.425 \\
(12.07)\end{array}$ & $\begin{array}{c}0.545 \\
(15.19)\end{array}$ & $\begin{array}{c}0.904 \\
(16.47)\end{array}$ \\
\hline $\begin{array}{l}\text { EWBHAR } \\
(t \text {-stat })\end{array}$ & $(5)$ & $\begin{array}{l}0.010 \\
(2.14)\end{array}$ & $\begin{array}{l}0.018 \\
(2.36)\end{array}$ & $\begin{array}{l}0.035 \\
(3.10)\end{array}$ & $\begin{array}{l}0.052 \\
(3.45)\end{array}$ & $\begin{array}{l}0.112 \\
(3.98)\end{array}$ & $\begin{array}{l}0.121 \\
(3.60)\end{array}$ & $\begin{array}{l}0.246 \\
(4.96)\end{array}$ \\
\hline $\begin{array}{l}\text { VWBHAR } \\
(t \text {-stats })\end{array}$ & (6) & $\begin{array}{l}0.011 \\
(2.34)\end{array}$ & $\begin{array}{l}0.020 \\
(2.64)\end{array}$ & $\begin{array}{l}0.037 \\
(3.34)\end{array}$ & $\begin{array}{l}0.056 \\
(3.70)\end{array}$ & $\begin{array}{l}0.116 \\
(4.16)\end{array}$ & $\begin{array}{l}0.128 \\
(3.85)\end{array}$ & $\begin{array}{l}0.256 \\
(5.14)\end{array}$ \\
\hline \multicolumn{9}{|c|}{ Panel C: Renegotiations with negative 3-day announcement CARs (7,961 obs) } \\
\hline $\begin{array}{l}\text { BHR } \\
(t \text {-stat })\end{array}$ & $(7)$ & $\begin{array}{l}0.028 \\
(6.21)\end{array}$ & $\begin{array}{l}0.055 \\
(7.65)\end{array}$ & $\begin{array}{c}0.122 \\
(10.44)\end{array}$ & $\begin{array}{c}0.256 \\
(12.25)\end{array}$ & $\begin{array}{c}0.413 \\
(10.39)\end{array}$ & $\begin{array}{c}0.540 \\
(13.10)\end{array}$ & $\begin{array}{c}0.772 \\
(17.06)\end{array}$ \\
\hline $\begin{array}{l}\text { EWBHAR } \\
(t \text {-stat })\end{array}$ & $(8)$ & $\begin{array}{l}0.003 \\
(0.72)\end{array}$ & $\begin{array}{l}0.003 \\
(0.49)\end{array}$ & $\begin{array}{l}0.026 \\
(2.35)\end{array}$ & $\begin{array}{l}0.041 \\
(2.51)\end{array}$ & $\begin{array}{l}0.097 \\
(3.04)\end{array}$ & $\begin{array}{l}0.114 \\
(3.10)\end{array}$ & $\begin{array}{l}0.123 \\
(3.16)\end{array}$ \\
\hline $\begin{array}{l}\text { VWBHAR } \\
(t \text {-stat })\end{array}$ & $(9)$ & $\begin{array}{l}0.004 \\
(0.96)\end{array}$ & $\begin{array}{l}0.005 \\
(0.70)\end{array}$ & $\begin{array}{l}0.029 \\
(2.55)\end{array}$ & $\begin{array}{l}0.044 \\
(2.68)\end{array}$ & $\begin{array}{l}0.100 \\
(3.13)\end{array}$ & $\begin{array}{l}0.117 \\
(3.19)\end{array}$ & $\begin{array}{l}0.129 \\
(3.32)\end{array}$ \\
\hline
\end{tabular}

This table presents the buy-and-hold abnormal returns after debt renegotiations. Firm-specific BHARs are measured as the buyand-hold raw return for the appropriate horizon minus the buy-and-hold return for a benchmark portfolio matched on size, book-to-market equity ratio, profitability, and investment (factors in Fama-French 2015). Size equals the natural log of the market value of equity. BTM equals the book-to-market equity ratio. Profitability equals sales minus cost of goods sold, interest expense, and selling, general and administrative expenses, divided by book value of equity. Investment equals the growth of total assets. EWBHAR and VWBHAR consider the weight of firms in the reference portfolio as equal-weighted or valueweighted by firm size prior to the renegotiations. The abnormal returns are the means of BHARs of renegotiating firms for appropriate horizons. Panel A presents results for all renegotiating firms. Panels B and C present results for renegotiating firms with positive and negative initial market responses, respectively, proxied by the 3-day CAR around the renegotiation events. 
TABLE 4

Long-run Abnormal Stock Returns by Amended Item

\begin{tabular}{|c|c|c|c|c|c|c|c|c|}
\hline & & 3-month & 6-month & 1-year & 2-year & 3-year & 4-year & 5-year \\
\hline \multicolumn{9}{|c|}{ Panel A: Borrowing amount $(5,986$ obs $)$} \\
\hline \multirow{2}{*}{$\begin{array}{l}\text { EWBHAR } \\
\text { (t-stats) }\end{array}$} & \multirow{2}{*}{ (1) } & 0.002 & 0.005 & 0.040 & 0.074 & 0.169 & 0.194 & 0.207 \\
\hline & & 0.39 & 0.58 & 2.52 & 3.31 & 3.34 & 3.34 & 3.53 \\
\hline \multicolumn{9}{|c|}{ Panel B: Maturity (4,167 obs) } \\
\hline \multirow{2}{*}{\multicolumn{2}{|c|}{$\begin{array}{l}\text { EWBHAR } \\
\text { (t-stats) }\end{array}$}} & 0.005 & -0.005 & 0.005 & 0.022 & 0.069 & 0.083 & 0.140 \\
\hline & & 0.78 & -0.71 & 0.58 & 1.35 & 3.05 & 2.72 & 2.88 \\
\hline \multicolumn{9}{|c|}{ Panel C: Pricing terms $(3,075$ obs $)$} \\
\hline \multirow{2}{*}{$\begin{array}{l}\text { EWBHAR } \\
\text { (t-stats) }\end{array}$} & \multirow{2}{*}{ (3) } & 0.011 & 0.009 & 0.053 & 0.092 & 0.131 & 0.155 & 0.275 \\
\hline & & 1.25 & 0.67 & 2.53 & 3.51 & 4.12 & 3.57 & 4.46 \\
\hline \multicolumn{9}{|c|}{ Panel D: Financial covenants $(3,502$ obs $)$} \\
\hline \multirow{2}{*}{$\begin{array}{l}\text { EWBHAR } \\
\text { (t-stats) }\end{array}$} & & 0.004 & 0.013 & 0.043 & 0.087 & 0.227 & 0.318 & 0.472 \\
\hline & & 0.59 & 1.16 & 2.69 & 3.07 & 4.13 & 4.09 & 4.75 \\
\hline \multicolumn{9}{|c|}{ Panel E: Corporate event-specific covenants (3,394 obs) } \\
\hline \multirow{2}{*}{$\begin{array}{l}\text { EWBHAR } \\
\text { (t-stats) }\end{array}$} & & -0.008 & 0.000 & -0.003 & 0.006 & 0.034 & 0.058 & 0.093 \\
\hline & & -1.52 & 0.02 & -0.21 & 0.32 & 1.44 & 1.87 & 2.24 \\
\hline \multicolumn{9}{|c|}{ Panel F: Waiver / consent $(1,892$ obs $)$} \\
\hline \multirow{2}{*}{$\begin{array}{l}\text { EWBHAR } \\
\text { (t-stats) }\end{array}$} & \multirow{2}{*}{ (6) } & -0.013 & 0.006 & 0.043 & 0.102 & 0.234 & 0.432 & 0.535 \\
\hline & & -1.02 & 0.18 & 1.25 & 1.80 & 2.36 & 2.83 & 3.00 \\
\hline \multicolumn{9}{|c|}{ Panel G: Addition of contractual parties (364 obs) } \\
\hline EWBHAR & (7) & 0.023 & -0.006 & -0.013 & -0.014 & 0.044 & -0.043 & -0.012 \\
\hline (t-stats) & & 0.85 & -0.24 & -0.41 & -0.38 & 0.84 & -0.64 & -0.10 \\
\hline
\end{tabular}

This table presents the buy-and-hold abnormal returns after debt renegotiations by different amended terms. We consider six types of amended provisions in Panels A through $\mathrm{G}$ - borrowing amount, maturity, pricing terms, financial covenants, corporate event-specific covenants, waivers and consent, and addition of contractual parties. 
TABLE 5

Long-run Abnormal Stock Returns by Renegotiation Round

\begin{tabular}{|c|c|c|c|c|c|c|c|c|}
\hline & & 3-month & 6-month & 1-year & 2-year & 3-year & 4-year & 5-year \\
\hline \multicolumn{9}{|c|}{ Panel A: Renegotiation Round $==1 / 2(5,481 \mathrm{obs})$} \\
\hline $\begin{array}{l}\text { EWBHAR } \\
\text { (t-stat) }\end{array}$ & & $\begin{array}{l}0.007 \\
(1.58)\end{array}$ & $\begin{array}{l}0.015 \\
(1.96)\end{array}$ & $\begin{array}{l}0.032 \\
(2.84)\end{array}$ & $\begin{array}{l}0.040 \\
(2.55)\end{array}$ & $\begin{array}{l}0.068 \\
(3.24)\end{array}$ & $\begin{array}{l}0.079 \\
(2.88)\end{array}$ & $\begin{array}{l}0.185 \\
(3.99)\end{array}$ \\
\hline \multicolumn{9}{|c|}{ Panel B: Renegotiation Round $==3 / 4(3,037$ obs $)$} \\
\hline $\begin{array}{l}\text { EWBHAR } \\
(t \text {-stat })\end{array}$ & (2) & $\begin{array}{l}0.009 \\
(1.11)\end{array}$ & $\begin{array}{l}0.000 \\
(0.02)\end{array}$ & $\begin{array}{l}0.007 \\
(0.42)\end{array}$ & $\begin{array}{l}0.027 \\
(1.06)\end{array}$ & $\begin{array}{l}0.117 \\
(2.23)\end{array}$ & $\begin{array}{l}0.132 \\
(1.73)\end{array}$ & $\begin{array}{l}0.201 \\
(2.10)\end{array}$ \\
\hline \multicolumn{9}{|c|}{ Panel C: Renegotiation Round $>=5(2,140$ obs $)$} \\
\hline $\begin{array}{l}\text { EWBHAR } \\
(t \text {-stat })\end{array}$ & (3) & $\begin{array}{l}0.007 \\
(0.69) \\
\end{array}$ & $\begin{array}{l}0.036 \\
(2.40) \\
\end{array}$ & $\begin{array}{l}0.080 \\
(3.10) \\
\end{array}$ & $\begin{array}{l}0.120 \\
(2.67) \\
\end{array}$ & $\begin{array}{l}0.295 \\
(2.34) \\
\end{array}$ & $\begin{array}{l}0.284 \\
(2.31) \\
\end{array}$ & $\begin{array}{l}0.334 \\
(2.51) \\
\end{array}$ \\
\hline
\end{tabular}

This table presents the buy-and-hold abnormal returns after debt renegotiations for different renegotiation rounds. Panels A through $\mathrm{C}$ show results for early-round (i.e., round one and two), middle-round (i.e., round three and four), and late-round (i.e., round five and beyond) renegotiations, respectively. 
TABLE 6

Long-run Abnormal Stock Returns by Borrower Characteristics

\begin{tabular}{|c|c|c|c|c|c|c|c|c|}
\hline & & 3-month & 6-month & 1-year & 2-year & 3-year & 4-year & 5-year \\
\hline \multicolumn{9}{|c|}{ Panel A: Borrower size $(15,849$ obs $)$} \\
\hline $\begin{array}{l}\text { EWBHAR - above median } \\
\text { ( } t \text {-stat })\end{array}$ & $(1)$ & $\begin{array}{l}-0.004 \\
(-1.44)\end{array}$ & $\begin{array}{l}-0.012 \\
(-1.22)\end{array}$ & $\begin{array}{l}-0.015 \\
(-0.91)\end{array}$ & $\begin{array}{l}-0.015 \\
(-0.63)\end{array}$ & $\begin{array}{l}-0.002 \\
(-0.18)\end{array}$ & $\begin{array}{l}-0.011 \\
(-0.59)\end{array}$ & $\begin{array}{l}-0.009 \\
(-0.39)\end{array}$ \\
\hline $\begin{array}{l}\text { EWBHAR - below median } \\
(t \text {-stat })\end{array}$ & $(2)$ & $\begin{array}{l}0.018 \\
(3.03)\end{array}$ & $\begin{array}{l}0.034 \\
(3.50)\end{array}$ & $\begin{array}{l}0.078 \\
(5.12)\end{array}$ & $\begin{array}{l}0.116 \\
(5.44)\end{array}$ & $\begin{array}{l}0.232 \\
(5.27)\end{array}$ & $\begin{array}{l}0.281 \\
(5.41)\end{array}$ & $\begin{array}{l}0.441 \\
(6.56)\end{array}$ \\
\hline \multicolumn{9}{|c|}{ Panel B: Number of analysts following $(15,849$ obs $)$} \\
\hline $\begin{array}{l}\text { EWBHAR - above median } \\
(t \text {-stat })\end{array}$ & (3) & $\begin{array}{l}0.001 \\
(0.28)\end{array}$ & $\begin{array}{l}0.006 \\
(1.09)\end{array}$ & $\begin{array}{l}0.000 \\
(0.05)\end{array}$ & $\begin{array}{l}-0.008 \\
(-0.69)\end{array}$ & $\begin{array}{l}-0.008 \\
(-0.59)\end{array}$ & $\begin{array}{l}-0.022 \\
(-0.72)\end{array}$ & $\begin{array}{l}0.002 \\
(0.06)\end{array}$ \\
\hline $\begin{array}{l}\text { EWBHAR - below median } \\
(t \text {-stat })\end{array}$ & $(4)$ & $\begin{array}{l}0.012 \\
(2.19)\end{array}$ & $\begin{array}{l}0.015 \\
(1.77)\end{array}$ & $\begin{array}{l}0.058 \\
(4.28)\end{array}$ & $\begin{array}{l}0.098 \\
(5.16)\end{array}$ & $\begin{array}{l}0.215 \\
(5.42)\end{array}$ & $\begin{array}{l}0.258 \\
(5.56)\end{array}$ & $\begin{array}{l}0.374 \\
(6.44)\end{array}$ \\
\hline \multicolumn{9}{|c|}{ Panel C: Leverage ratio $(15,849$ obs $)$} \\
\hline $\begin{array}{l}\text { EWBHAR - above median } \\
(t \text {-stat })\end{array}$ & $(5)$ & $\begin{array}{l}0.008 \\
(1.67)\end{array}$ & $\begin{array}{l}0.015 \\
(1.69)\end{array}$ & $\begin{array}{l}0.049 \\
(3.44)\end{array}$ & $\begin{array}{l}0.073 \\
(3.75)\end{array}$ & $\begin{array}{l}0.147 \\
(3.62)\end{array}$ & $\begin{array}{l}0.167 \\
(4.36)\end{array}$ & $\begin{array}{l}0.215 \\
(4.53)\end{array}$ \\
\hline $\begin{array}{l}\text { EWBHAR - below median } \\
(t \text {-stat })\end{array}$ & $(6)$ & $\begin{array}{l}0.005 \\
(1.20)\end{array}$ & $\begin{array}{l}0.007 \\
(1.22)\end{array}$ & $\begin{array}{l}0.013 \\
(1.73)\end{array}$ & $\begin{array}{l}0.021 \\
(1.86)\end{array}$ & $\begin{array}{l}0.065 \\
(2.91)\end{array}$ & $\begin{array}{l}0.082 \\
(3.78)\end{array}$ & $\begin{array}{l}0.154 \\
(3.99)\end{array}$ \\
\hline
\end{tabular}

This table presents the buy-and-hold abnormal returns after debt renegotiations by three firm characteristics - firm size, the number of analysts following, and the leverage ratio. Size is defined as the natural log of firms' market value of equity. Number of analysts following is defined by the total number of analysts following a firm on I/B/E/S. Leverage ratio is defined as the ratio of total debt over total assets. Firms are separated into above-median and below-median groups based on the median of the specific measure in each year. Panel A through C presents results using the three measures, respectively. Rows (1), (3), and (5) show results of the above-median groups, and rows (2), (4), and (6) display results of the below-median groups. 
TABLE 7

The Behavior of Accounting-based Performance Measures around Renegotiations

\begin{tabular}{|c|c|c|c|c|c|c|}
\hline & (1) & (2) & (3) & (4) & (5) & (6) \\
\hline & CAPX & WCAP & ROA & $\mathrm{CF}$ & Z-score & O-score \\
\hline \multirow[t]{2}{*}{ Year $_{-2}$} & 0.003 & 0.006 & $0.012 * * *$ & $0.004 * * *$ & $0.361 * * *$ & $-0.264 * * *$ \\
\hline & $(1.49)$ & $(1.13)$ & $(5.60)$ & $(3.08)$ & $(8.67)$ & $(-7.16)$ \\
\hline \multirow[t]{2}{*}{ Year $_{-1}$} & 0.003 & -0.008 & $0.009 * * *$ & 0.001 & $0.223 * * *$ & $-0.108 * * *$ \\
\hline & $(1.30)$ & $(-1.54)$ & $(4.12)$ & $(1.33)$ & $(7.60)$ & $(-3.30)$ \\
\hline \multirow[t]{2}{*}{ Year $_{1}$} & $0.012 * * *$ & $0.071 * * *$ & -0.001 & $0.002 *$ & $0.146 * * *$ & $0.115^{* * *}$ \\
\hline & $(7.57)$ & $(17.28)$ & $(-0.62)$ & $(1.96)$ & $(5.45)$ & $(4.03)$ \\
\hline \multirow[t]{2}{*}{ Year $_{2}$} & $0.016^{* * *}$ & $0.072 * * *$ & $0.004 *$ & $0.006 * * *$ & $0.186^{* * *}$ & $-0.145^{* * *}$ \\
\hline & $(8.01)$ & $(16.64)$ & (1.68) & $(4.30)$ & $(5.43)$ & $(-4.33)$ \\
\hline \multirow[t]{2}{*}{ Year $_{3}$} & $0.018 * * *$ & $0.081 * * *$ & $0.009 * * *$ & $0.008 * * *$ & $0.212 * * *$ & $-0.173 * * *$ \\
\hline & $(7.78)$ & $(17.44)$ & $(3.78)$ & $(5.11)$ & $(5.24)$ & $(-4.72)$ \\
\hline \multirow[t]{2}{*}{ Year $_{4}$} & $0.018 * * *$ & $0.089 * * *$ & $0.013 * * *$ & $0.007 * * *$ & $0.269 * * *$ & $-0.247 * * *$ \\
\hline & $(7.08)$ & $(18.08)$ & $(5.28)$ & $(4.20)$ & $(5.32)$ & $(-5.98)$ \\
\hline \multirow[t]{2}{*}{ Year$_{5}$} & $0.020 * * *$ & $0.094 * * *$ & $0.011 * * *$ & $0.005^{* * *}$ & $0.285^{* * *}$ & $-0.256 * * *$ \\
\hline & $(7.56)$ & $(17.67)$ & $(4.29)$ & $(3.30)$ & $(5.07)$ & $(-5.47)$ \\
\hline Observations & 86,544 & 88,934 & 88,936 & 89,045 & 84,790 & 87,658 \\
\hline R-squared & 0.048 & 0.107 & 0.014 & 0.032 & 0.073 & 0.040 \\
\hline Fixed Effects & \multicolumn{6}{|c|}{ Industry } \\
\hline
\end{tabular}

This table presents the regressions results of the following model:

$$
\text { ACC_PERF }=\beta_{0}+\beta_{1} \text { Year }_{-2}+\beta_{2} \text { Year }_{-1}+\beta_{3} \text { Year }_{1}+\beta_{4} \text { Year }_{2}+\beta_{5} \text { Year }_{3}+\beta_{6} \text { Year }_{4}+\beta_{7} \text { Year }_{5}+\text { Industry FE }+\varepsilon
$$

We regress firms' accounting performance measures on the year relative to the renegotiation year. Columns (1) - (6) present the results for the six fundamental measures we consider - CAPX, WCAP, ROA, CF, Z-score, and O-score, defined as follows: (1) CAPX is capital expenditure scaled by lagged plant, property and equipment; (2) WCAP is working capital, computed by the difference of current assets and current liabilities, divided by lagged total assets; (3) ROA is the ratio of net income over total assets; (4) CF is the ratio of operating cash flow over total assets. (5) Altman Z-score is the bankruptcy risk metric developed by Altman 
(1968); and (6) Ohlson O-score is a financial distress metric developed by Ohlson (1980). All the measures are defined against a benchmark portfolio matched on size, book-to-market equity ratio, profitability, and investment (factors in Fama-French 2015). The standard errors are clustered by firm. 
TABLE 8

Long-run Abnormal Stock Returns Conditioned on Changes in Accounting Performance

\begin{tabular}{|c|c|c|c|c|c|c|c|c|}
\hline & & 3-month & 6-month & 1-year & 2-year & 3-year & 4-year & 5-year \\
\hline \multicolumn{9}{|c|}{ Panel A: Cross-sectional analysis by the change of CAPX $(12,040 \mathrm{obs})$} \\
\hline $\begin{array}{l}\text { EWBHAR - above median } \\
(t \text {-stat })\end{array}$ & $(1)$ & $\begin{array}{l}0.011 \\
(2.17)\end{array}$ & $\begin{array}{l}0.025 \\
(3.30)\end{array}$ & $\begin{array}{l}0.074 \\
(5.54)\end{array}$ & $\begin{array}{l}0.128 \\
(6.49)\end{array}$ & $\begin{array}{l}0.261 \\
(5.74)\end{array}$ & $\begin{array}{l}0.279 \\
(5.60)\end{array}$ & $\begin{array}{l}0.356 \\
(5.99)\end{array}$ \\
\hline $\begin{array}{l}\text { EWBHAR - below median } \\
(t \text {-stat })\end{array}$ & (2) & $\begin{array}{l}0.004 \\
(0.83)\end{array}$ & $\begin{array}{r}0.000 \\
(-0.02)\end{array}$ & $\begin{array}{l}-0.007 \\
(-0.81)\end{array}$ & $\begin{array}{l}-0.013 \\
(-0.87)\end{array}$ & $\begin{array}{l}-0.021 \\
(-1.15)\end{array}$ & $\begin{array}{l}-0.007 \\
(-0.30)\end{array}$ & $\begin{array}{l}0.042 \\
(1.12)\end{array}$ \\
\hline \multicolumn{9}{|c|}{ Panel B: Cross-sectional analysis by the change of WCAP $(11,962 \mathrm{obs})$} \\
\hline $\begin{array}{l}\text { EWBHAR - above median } \\
\text { ( } t \text {-stat) }\end{array}$ & (3) & $\begin{array}{l}0.016 \\
(3.13)\end{array}$ & $\begin{array}{l}0.036 \\
(4.56)\end{array}$ & $\begin{array}{l}0.081 \\
(6.07)\end{array}$ & $\begin{array}{l}0.132 \\
(6.74)\end{array}$ & $\begin{array}{l}0.249 \\
(5.45)\end{array}$ & $\begin{array}{l}0.296 \\
(5.95)\end{array}$ & $\begin{array}{l}0.401 \\
(6.64)\end{array}$ \\
\hline $\begin{array}{l}\text { EWBHAR - below median } \\
(t \text {-stat })\end{array}$ & (4) & $\begin{array}{l}-0.002 \\
(-0.47)\end{array}$ & $\begin{array}{l}-0.011 \\
(-1.80)\end{array}$ & $\begin{array}{l}-0.014 \\
(-1.63)\end{array}$ & $\begin{array}{l}-0.018 \\
(-1.26)\end{array}$ & $\begin{array}{l}-0.002 \\
(-0.11)\end{array}$ & $\begin{array}{l}-0.020 \\
(-0.84)\end{array}$ & $\begin{array}{l}0.005 \\
(0.14)\end{array}$ \\
\hline
\end{tabular}

Panel C: Cross-sectional analysis by the change of ROA (13,182 obs)

$\begin{array}{lcccccccc}\text { EWBHAR - above median } & (5) & 0.025 & 0.051 & 0.120 & 0.216 & 0.381 & 0.472 & 0.597 \\ (t \text {-stat }) & & (5.04) & (6.96) & (9.77) & (11.12) & (8.35) & (9.33) & (9.78) \\ \text { EWBHAR - below median } & (6) & -0.011 & -0.027 & -0.054 & -0.105 & -0.143 & -0.209 & -0.215 \\ (t \text {-stat }) & & (-2.54) & (-3.92) & (-5.48) & (-7.30) & (-8.65) & (-10.22) & (-6.61)\end{array}$

Panel D: Cross-sectional analysis by the change of CF $(13,182 \mathrm{obs})$

$\begin{array}{lcccccccc}\text { EWBHAR - above median } & (7) & 0.023 & 0.042 & 0.100 & 0.181 & 0.324 & 0.377 & 0.522 \\ (t \text {-stat }) & & (4.45) & (5.13) & (7.60) & (8.87) & (6.97) & (7.44) & (8.28) \\ \text { EWBHAR - below median } & (8) & -0.009 & -0.017 & -0.033 & -0.068 & -0.080 & -0.107 & -0.125 \\ (t \text {-stat }) & & (-2.03) & (-2.80) & (-3.71) & (-5.14) & (-5.06) & (-4.85) & (-4.01) \\ & & & 49 & & & & \end{array}$




\section{Panel E: Cross-sectional analysis by the change of Z-score (11,577 obs)}

$\begin{array}{lcccccccc}\text { EWBHAR - above median } & (9) & 0.022 & 0.049 & 0.104 & 0.201 & 0.355 & 0.400 & 0.509 \\ (t \text {-stat }) & & (4.56) & (6.77) & (8.42) & (9.65) & (7.47) & (7.83) & (9.30) \\ \text { EWBHAR - below median } & (10) & -0.007 & -0.020 & -0.028 & -0.076 & -0.090 & -0.102 & -0.083 \\ (t \text {-stat }) & & (-1.38) & (-2.58) & (-2.51) & (-5.26) & (-4.58) & (-3.80) & (-1.64)\end{array}$

Panel F: Cross-sectional analysis by the change of $O$-score $(10,828$ obs)

\begin{tabular}{lcccccccc} 
EWBHAR - above median & $(11)$ & 0.009 & 0.012 & 0.033 & 0.032 & 0.117 & 0.122 & 0.190 \\
$(t$-stat $)$ & & $(1.66)$ & $(1.49)$ & $(2.25)$ & $(1.47)$ & $(2.29)$ & $(2.17)$ & $(2.80)$ \\
EWBHAR - below median & $(12)$ & 0.005 & 0.013 & 0.040 & 0.088 & 0.148 & 0.204 & 0.278 \\
$(t$-stat $)$ & & $(1.09)$ & $(1.79)$ & $(4.48)$ & $(5.72)$ & $(6.85)$ & $(6.83)$ & $(6.07)$ \\
\hline \hline
\end{tabular}

This table presents the buy-and-hold abnormal returns after debt renegotiations by the performance change during the pre and post period around renegotiation. We consider six accounting performance measures - CAPX, WCAP, ROA, CF, Z-score, and O-score, defined as follows: (1) CAPX is capital expenditure scaled by lagged plant, property and equipment; (2) WCAP is working capital, computed by the difference of current assets and current liabilities, divided by lagged total assets; (3) ROA is the ratio of net income over total assets; (4) CF is the ratio of operating cash flow over total assets. (5) Altman Z-score is the bankruptcy risk metric developed by Altman (1968); and (6) Ohlson O-score is a financial distress metric developed by Ohlson (1980). All the measures are defined against a benchmark portfolio matched on size, book-to-market equity ratio, profitability, and investment (factors in Fama-French 2015). We define pre period as the two years prior to the renegotiation year, and post period as the six years (including the renegotiation year) after the renegotiation, and calculate the performance change as the difference of the performance measures during the pre and post period. Panel A through F presents results using the six measures, respectively. In each panel, the first row shows results of the above-median groups, and the second row displays results of the below-median groups. 
TABLE 9

Sensitivity Tests: One-to-one Matching

\begin{tabular}{|c|c|c|c|c|c|c|c|c|}
\hline & & 3-month & 6-month & 1-year & 2-year & 3-year & 4-year & 5-year \\
\hline \multicolumn{9}{|c|}{ Panel A: All renegotiations $(15,738$ obs $)$} \\
\hline $\begin{array}{l}\text { BHAR - matching method (1) } \\
(t \text {-stat) }\end{array}$ & $(1)$ & $\begin{array}{l}0.005 \\
(1.14)\end{array}$ & $\begin{array}{l}0.011 \\
(1.82)\end{array}$ & $\begin{array}{l}0.025 \\
(2.72)\end{array}$ & $\begin{array}{l}0.067 \\
(4.20)\end{array}$ & $\begin{array}{l}0.156 \\
(5.59)\end{array}$ & $\begin{array}{l}0.195 \\
(6.49)\end{array}$ & $\begin{array}{l}0.273 \\
(6.92)\end{array}$ \\
\hline $\begin{array}{l}\text { BHAR - matching method (2) } \\
(t \text {-stat) }\end{array}$ & $(2)$ & $\begin{array}{l}0.004 \\
(0.91)\end{array}$ & $\begin{array}{l}0.004 \\
(0.74)\end{array}$ & $\begin{array}{l}0.021 \\
(2.28)\end{array}$ & $\begin{array}{l}0.050 \\
(3.09)\end{array}$ & $\begin{array}{l}0.102 \\
(3.64)\end{array}$ & $\begin{array}{l}0.078 \\
(3.29)\end{array}$ & $\begin{array}{l}0.196 \\
(4.85)\end{array}$ \\
\hline \multicolumn{9}{|c|}{ Panel B: Renegotiations with positive 3-day announcement CAR (7,837 obs) } \\
\hline $\begin{array}{l}\text { BHAR - matching method (1) } \\
(t \text {-stat) }\end{array}$ & $(3)$ & $\begin{array}{l}0.007 \\
(1.09)\end{array}$ & $\begin{array}{l}0.016 \\
(1.77)\end{array}$ & $\begin{array}{l}0.024 \\
(1.82)\end{array}$ & $\begin{array}{l}0.066 \\
(2.89)\end{array}$ & $\begin{array}{l}0.159 \\
(4.26)\end{array}$ & $\begin{array}{l}0.195 \\
(4.78)\end{array}$ & $\begin{array}{l}0.326 \\
(5.30)\end{array}$ \\
\hline $\begin{array}{l}\text { BHAR - matching method (2) } \\
(t \text {-stat) }\end{array}$ & (4) & $\begin{array}{l}0.004 \\
(0.72)\end{array}$ & $\begin{array}{l}0.005 \\
(0.51)\end{array}$ & $\begin{array}{l}0.020 \\
(1.46)\end{array}$ & $\begin{array}{l}0.045 \\
(1.97)\end{array}$ & $\begin{array}{l}0.087 \\
(2.49)\end{array}$ & $\begin{array}{l}0.062 \\
(2.70)\end{array}$ & $\begin{array}{l}0.218 \\
(3.45)\end{array}$ \\
\hline \multicolumn{9}{|c|}{ Panel C: Renegotiations with negative 3-day announcement CAR (7,901 obs) } \\
\hline $\begin{array}{l}\text { BHAR - matching method (1) } \\
\text { (t-stat) }\end{array}$ & $(5)$ & $\begin{array}{l}0.003 \\
(0.52)\end{array}$ & $\begin{array}{l}0.006 \\
(0.78)\end{array}$ & $\begin{array}{l}0.027 \\
(2.02)\end{array}$ & $\begin{array}{l}0.069 \\
(3.05)\end{array}$ & $\begin{array}{l}0.153 \\
(3.69)\end{array}$ & $\begin{array}{l}0.195 \\
(4.42)\end{array}$ & $\begin{array}{l}0.221 \\
(4.44)\end{array}$ \\
\hline $\begin{array}{l}\text { BHAR - matching method (2) } \\
(t \text {-stat) }\end{array}$ & (6) & $\begin{array}{l}0.003 \\
(0.56) \\
\end{array}$ & $\begin{array}{l}0.004 \\
(0.54) \\
\end{array}$ & $\begin{array}{l}0.023 \\
(1.77) \\
\end{array}$ & $\begin{array}{l}0.056 \\
(2.39) \\
\end{array}$ & $\begin{array}{l}0.118 \\
(2.67) \\
\end{array}$ & $\begin{array}{l}0.094 \\
(2.36) \\
\end{array}$ & $\begin{array}{l}0.174 \\
(3.45) \\
\end{array}$ \\
\hline
\end{tabular}

This table presents the buy-and-hold abnormal returns after debt renegotiations. Instead of matching each renegotiating firm with a portfolio, we conduct a one-toone matching to find the reference firm. The firm-specific BHARs are computed as the buy-and-hold raw return for the appropriate horizon minus the buy-andhold return for the benchmark firm. We use (1) firm size and book-to-market ratio, and (2) industry and firm size, to find the benchmark firm. Panel A presents results for all renegotiating firms. Panel B and C present results for renegotiating firms with positive and negative initial market responses, respectively, proxied by the 3-day CAR around the renegotiation event. In each panel, we report the abnormal returns computed by the two matching methods. 
TABLE 10

Sensitivity Tests: Fama-Macbeth Approach

\begin{tabular}{|c|c|c|c|c|c|c|c|}
\hline & 3-month & 6-month & 1-year & 2-year & 3-year & 4-year & 5-year \\
\hline \multicolumn{8}{|c|}{ Panel A: All renegotiations } \\
\hline AR & 0.0021 & 0.0020 & 0.0023 & 0.0022 & 0.0022 & 0.0023 & 0.0024 \\
\hline$(t$-stat) & $(1.32)$ & $(1.43)$ & $(1.74)$ & $(1.81)$ & $(1.88)$ & $(1.97)$ & $(2.18)$ \\
\hline \multicolumn{8}{|c|}{ Panel B: Renegotiations with positive announcement CAR } \\
\hline AR & 0.0033 & 0.0024 & 0.0030 & 0.0025 & 0.0024 & 0.0023 & 0.0025 \\
\hline$(t$-stat $)$ & $(1.78)$ & $(1.47)$ & $(2.02)$ & $(1.98)$ & $(1.95)$ & $(2.00)$ & $(2.10)$ \\
\hline \multicolumn{8}{|c|}{ Panel C: Renegotiations with negative announcement CAR } \\
\hline AR & 0.0009 & 0.0017 & 0.0015 & 0.0019 & 0.0020 & 0.0020 & 0.0020 \\
\hline$(t$-stat $)$ & $(0.55)$ & $(1.19)$ & $(1.14)$ & $(1.55)$ & $(1.69)$ & $(1.67)$ & $(1.70)$ \\
\hline
\end{tabular}

This table presents the average coefficients and t-statistics of Fama-Macbeth regression on all renegotiations, and renegotiations with positive and negative initial market response, proxied by the 3-day CAR around the renegotiations. Specifically, we conduct a monthly estimation of the following cross-sectional regression:

$$
\text { RETURN }=\alpha+\beta_{1} \text { Size }+\beta_{2} \text { BTM }+\beta_{3} \text { Profitability }+\beta_{4} \text { Investment }+\beta_{5}(\text { RENEGOTIATION })
$$

RETURN is a raw monthly return. Size equals the natural log of market value of equity. BTM equals book-to-market equity ratio. Profitability equals sales minus cost of goods sold, interest expense, and selling, general and administrative expenses, divided by book value of equity. Investment equals the growth of total assets. The indicator RENEGOTIATION equals one if the firm renegotiated debt within the specified time horizon preceding the monthly return, and zero otherwise. The indicator RENEGOTIATION refers to all renegotiations in Panel A and refers to the renegotiations with positive and negative CAR (1,1) in Panel B and C, respectively. 